\title{
Consequences of pinyon and juniper woodland reduction for wildlife in North America
}

Sara Bombaci ${ }^{\text {a }}$ (Corresponding Author)

Liba Pejchar ${ }^{\mathrm{b}}$

aDepartment of Fish, Wildlife and Conservation Biology, 1474 Campus Delivery, Colorado State University, Fort, Collins, CO 80523, USA, sbombaci@mail.colostate.edu

${ }^{\mathrm{b}}$ Department of Fish, Wildlife and Conservation Biology, 1474 Campus Delivery, Colorado State University, Fort, Collins, CO 80523, USA, liba.pejchar@colostate.edu 


\section{ABSTRACT}

Pinyon and juniper (Pinus spp., Juniperus spp.) woodlands are expanding into shrublands and grasslands throughout much of western North America. Woodland reduction is frequently used to mitigate the effects of conifer encroachment on game species (e.g. mule deer Odocoileus hemionus) and shrub and grassland-obligate species (e.g. sage grouse Centrocercus spp.). Although these practices are widespread, previous studies on the effects of woodland reduction on animal communities have not yet been synthesized, making it difficult to set priorities for future research and practice. To address this gap, we first summarize the history of pinyon and juniper reduction in western North America and characterize known wildlife habitat associations in pinyon and juniper ecosystems. We then review and synthesize evidence from the scientific literature on wildlife responses to pinyon and juniper woodland reduction. We tallied the outcomes of these studies to determine the relative proportions of positive, negative, and nonsignificant responses by different taxonomic groups and functional groups. The majority (69\%) of animal species responses to woodland reduction treatments were non-significant. However, particular groups of species (taxonomic and/or functional) were more likely to respond positively or negatively, depending on the woodland reduction treatment method. Unexpectedly, investigators often found non-significant or negative responses by ungulates to woodland reduction, and non-significant responses by sagebrush obligate species. However, few studies measured effects on sagebrush obligate species, which limits inference for this group. Indeed, our review demonstrates that the effects of woodland reduction are well-understood for only a subset of taxonomic groups (e.g. birds and small mammals); whereas other groups (e.g. reptiles and terrestrial invertebrates) are consistently under-studied. Further, a shortage of large-scale and long-term research limits our ability to fully understand spatial and temporal wildlife responses to woodland reduction. We encourage practitioners to design and implement pinyon and juniper 
reduction projects to experimentally assess the effects of these practices on both target and nontarget species. Adopting consistent monitoring protocols across projects would also facilitate greater understanding of how factors such as treatment type, size, location and duration result in positive or negative impacts to diverse wildlife of conservation concern.

KEYWORDS: conifer removal, habitat restoration, woodland species, sagebrush obligate, woodland modification, pinyon juniper management 


\subsection{INTRODUCTION}

Pinyon and juniper (Pinus spp., Juniperus spp.) woodlands are one of the most extensive ecosystems in western North America (West 1984) and support a high diversity of animal species compared with many other plant communities in this region (Finch and Ruggerio 1993, Paulin et al. 1999). In certain areas, woodlands dominated by juniper trees, pinyon trees, or both (henceforth referred to as pinyon and juniper woodlands, irrespective of dominant cover type) have expanded in range and increased in stand density over the past century (Blackburn and Tueller 1970, Miller and Rose 1995, Miller and Rose 1999, Stevens 1999, Romme et al. 2009). The causes of this expansion have been attributed to numerous factors, including fire suppression, livestock grazing, natural recovery from disturbance, natural range expansion, altered climate patterns, and elevated carbon dioxide levels (Romme et al. 2009); yet the empirical evidence on the most important drivers of woodland expansion is mixed and incomplete (Romme et al. 2009). These woodlands are not expanding everywhere. For example, there has been extensive drought-induced woodland mortality, especially of Pinus edulis trees, in parts of the southwestern US (Breshears et al. 2005, Mueller et al. 2005, Floyd et al. 2009).

Where these woodlands have expanded into surrounding sage-steppe and forest ecosystems and are considered to impact species of economic or conservation concern, natural resouce managers have reduced pinyon and juniper overstory to limit its spread (Miller and Wigand 1994, Belsky 1996, Noson et al. 2006). In particular, pinyon and juniper woodland reduction has been widely-used to improve forage and habitat quality for rare species (e.g., sage grouse Centrocercus spp.), hunted species (e.g., mule deer Odocoileus hemionus), and livestock (Plummer et al. 1968, Stevens 1987, Baruch-Mordo et al. 2013, Bergman et al. 2014). The use of woodland reduction practices is increasing as resource managers try to meet the challenge of 
conserving and enhancing habitat for species sensitive to conifer encroachment (US Bureau of Land Management 2011, Baruch-Mordo et al. 2013, DOI 2013), and as a result of fuel reduction under the National Fire Plan (Schoennagel and Nelson 2011).

Woodland reduction to limit pinyon and juniper expansion or to enhance habitat for target species may not benefit all animal species; pinyon and juniper specialists may decline and effects are not well-understood for some taxonomic groups. Yet, there is no synthetic review summarizing the consequences of these practices for wildlife. Such a review is needed to evaluate the success and shortcomings of current woodland reduction practices for diverse species, and to set priorities for future research and management.

In the following review, we address this need by first briefly summarizing the history of pinyon and juniper woodland reduction activities in western North America. We then discuss the diversity of animal species associated with pinyon and juniper woodlands to provide context for understanding how woodland reduction will affect a variety of taxonomic groups. We later review and synthesize empirical evidence from the scientific literature to address our primary research questions: 1) what are the effects of woodland reduction on wildlife?, and 2) how do these effects vary across different taxonomic groups, functional groups, treatment methods, and temporal and spatial scales? We also identify the scope (i.e., geographic, spatial and temporal scales, taxonomic groups, and treatment methods) to which our findings apply and highlight future research priorities to fill major gaps in understanding. Finally, we draw on the results of this review to discuss how these findings can be used to inform woodland reduction strategies that achieve multi-species conservation objectives.

\subsection{PINYON AND JUNIPER WOODLAND REDUCTION HISTORY}


Pinyon and juniper woodlands cover 40 million ha of land in the United States (Romme et al. 2009) and are the third most extensive plant community in the country (West 1984). Pinyon-juniper stands have expanded into non woodland areas and increased in tree density throughout much, but not all, of their range over the last 100-150 years (see Romme et al. 2009 for a comprehensive review of the patterns and drivers of woodland expansion). These changes have had diverse consequences for plant and animal communities. Areas of high pinyon and juniper cover have been associated with decreased diversity and cover of understory shrubs, herbs and grasses (Blackburn and Tueller 1970, Tausch et al. 1981, Pieper 1990, Gottfried et al. 1995, Tausch and West 1995, Miller et al. 2000), and reduced numbers of understory seeds in the soil seed bank (Koniak and Everett 1982, Poulsen et al. 1999). These vegetative changes have reduced habitat quality for some wildlife species and livestock by reducing forage availability (Short et al. 1977, Short and McCulloch 1977, Hoenes et al. 2012). The loss of herbaceous cover in the understory may also make these stands more susceptible to soil erosion, with subsequent negative impacts on water quality (Roundy and Vernon 1999). However, others have suggested that the evidence on the impacts of increased pinyon and juniper cover on forage quality and erosion properties is inconsistent (Belsky 1996).

The demonstrated and perceived impacts of woodland expansion have often prompted land managers to reduce the density or limit the extent of pinyon and juniper woodlands using mechanical methods (e.g. chaining, bulldozing), or by thinning, prescribed fire, or combinations of mechanical removal and fire (Plummer et al. 1968, Aro 1971, Tausch and Tueller 1977, Stevens 1987, Evans 1988, West 1988, Stevens 1999, Redmond et al. 2014). Historically, chaining has been the method most widely employed by land managers to reduce pinyon and juniper woodlands (Aro 1971, Evans 1988, Redmond et al. 2014). Evans (1988) reported that 
over 100,000 acres had been chained by 1988 on land managed by the Forest Service and the Bureau of Land Management.

Woodland reduction efforts have had mixed results in terms of successfully reducing tree cover and preventing re-establishment (Tausch and Tueller 1977, Stevens 1987, Evans 1988, Van Pelt et al. 1990, Stevens and Walker 1996, Redmond et al. 2013, Bristow et al. 2014). Tausch and Tueller (1977) reported that trees steadily reinvaded and dominated sites within 15 years of treatment, leading to declines in understory herbaceous plant abundance and requiring re-treatment. Evans (1988) also recommended re-treatment to restore habitat and improve forage production in areas previously treated by chaining. Similarly, Bristow et al. (2014) found that junipers reinvaded sites treated with fire or chaining within 15 years, and that pinyon pines reinvaded sites within 15-40 years. However, others did not observe an increase in tree density or re-invasion after treatment, but in contrast, observed declines in tree density up to 30 years post treatment (Stevens 1987, Van Pelt et al. 1990, Stevens and Walker 1996). Furthermore, Redmond et al. (2013) found lower Pinus edulis recruitment in 20-40 year old tree reduction plots, but found no long-term effect of woodland reduction on Juniperus osteosperma recruitment.

\subsection{WILDLIFE USE OF PINYON AND JUNIPER WOODLANDS}

Changes in the distribution of pinyon and juniper woodlands due to expansion or reduction could be particularly important for faunal diversity because these plant communities support a large assemblage of wildlife species. At least 73 bird species breed in pinyon and juniper woodlands, of which approximately 30 are thought to breed regularly in this ecosystem (Balda and Masters 1980). Over half of these breeding birds are neotropical migrants (Balda and 
Masters 1980), and pinyon and juniper woodlands may provide essential breeding habitat for several species, especially blue-gray gnatcatchers (Polioptila caerulea), black-throated gray warblers (Setophaga nigrescens), gray flycatchers (Empidonax wrightii) (Webb 1999), and longeared owls (Paulson and Sieg 1984). Paulin et al. (1999) found that pinyon and juniper woodlands in Utah had more obligate and semi-obligate bird species than any other forest habitat type, except riparian woodlands. They also found higher abundance of all birds in pinyon and juniper woodlands than in all other habitats with the exception of aspen (populous tremuloides) and riparian woodlands. In addition, pinyon and juniper woodlands have the fourth highest bird species richness and diversity values relative to other North American forest types (Paulin et al. 1999). For these reasons, Paulin et al. (1999) contended that pinyon and juniper woodlands are very important for maintaining bird diversity at landscape scales.

Pinyon and juniper habitat supports bird diversity year-round (Sieg 1991). In comparison to surrounding grassland habitats, pinyon and juniper stands maintained a larger number of species and over double the number of individuals consistently through every season; additionally, twice as many species were found nesting in pinyon and juniper during the breeding season (Sieg 1991). Sieg (1991) noted that spring bird surveys may underestimate the year-long value of pinyon and juniper habitat for providing thermal cover and food resources for overwintering birds, corridors for migrating birds, and summer perching and nesting sites. However, Balda and Masters (1980) noted that some seasonal bird densities are closely tied to juniper berry production, which suggests that pinyon and juniper woodlands may not provide consistent winter food sources for some species.

Pinyon and juniper ecosystems also provide important habitat for mammals. Sixty-two mammal species were identified using pinyon and juniper woodlands in Colorado alone, which 
was higher than the number of mammal species found in all seven other forest types in Colorado (Finch and Ruggerio 1993). Several of these species are rarely found outside of pinyon and juniper woodlands, including pinyon mice (Peromyscus truei), cliff chipmunks (Tamias dorsalis), Yuma myotis (Myotis yumanensis), white-tailed antelope squirrels (Ammospermophilus leucurus), Apache pocket mice (Perognathus apache), desert woodrats (Neotoma lepida), kit foxes (Vulpes macrotis), ringtails (Bassarisdus astutus), and white-backed hog-nosed skunks (Conepatus mesoleucus ) (Finch and Ruggerio 1993). Additionally, ChungMacCoubrey (2005) found that bat diversity was higher in pinyon and juniper woodlands than in nearby ponderosa pine forests in New Mexico, and that pinyon and juniper woodlands may provide important breeding habitat for several bat species. Pinyon and juniper ecosystems may also supply critical wintering habitat for mule deer by providing thermal and security cover (Bender et al. 2007, Anderson et al. 2012), and important habitat for elk (Cervus elaphus), by providing bedding sites (Bender et al. 2012). Open pinyon and juniper stands with high understory herbaceous cover are particularly favorable to deer, elk, and many other wildlife species (Short and McCulloch 1977). Pinyon and juniper woodlands also provide specialized habitat and dispersal pathways for some woodland small mammals (e.g. white-footed mice (Peromyscus leucopus) and bushy-tailed woodrats (Neotoma cinerea) (Sieg 1988).

Small mammal habitat characteristics in pinyon and juniper woodlands have been wellstudied. Habitat preferences vary by species, depending on the level of canopy cover, tree dispersion, herbaceous understory cover, and sometimes cliff access (Ribble and Samson 1987, Rompola and Anderson 2004, Rodhouse et al. 2010). There are both positive and negative associations with these site-specific characteristics, depending on species; thus, maintaining 
heterogeneous overstory and understory cover in pinyon and juniper woodlands may enhance overall small mammal diversity.

Information on hepetofauna or invertebrate use of pinyon and juniper woodlands is very limited. However site characteristics such as rock outcrops and ant mounds may strongly influence reptile and amphibian abundance and diversity in these woodlands (Frischknecht 1975, Miller 2001). Additionally, invertebrate species may preferentially use herbaceous shrubs and grasses interspersed among pinyon and juniper woodlands (Frischknecht 1975). More than 300 invertebrate species were collected from three shrub species and one grass species found growing amid pinyon and juniper stands in Utah (Frischknecht 1975). Furthermore, 83 different invertebrate species were listed in Frischknecht (1975) that were collected in pinyon and juniper woodlands. Of these 83 species, $25 \%$ were Araneae, $13 \%$ were Chermidae, $12 \%$ were Formicidae, $8 \%$ were other Hymenoptera, $10 \%$ were Diptera, $9 \%$ were Cicadellidae, $6 \%$ were Hemiptera, 5\% were Coleoptera, $3 \%$ were Orthoptera, and 9\% were listed as other. Also, Brantley and Shepherd (2004) found 34 species of arthropods on cryptobiotic soil crusts in pinyon and juniper woodlands, including mites, collembolans, diplurans, pseudoscorpions, thrips, tardigrades, and nematodes.

\subsection{CONSEQUENCES OF WOODLAND REDUCTION FOR WILDLIFE}

\subsection{Literature Review Methodology}

We conducted a systematic review to evaluate and synthesize the effects of pinyon and juniper woodland reduction on wildlife. We searched for potential studies to include in our dataset using Web of Science and Google Scholar and the keywords in Appendix A. We reviewed all studies on wildlife responses to woodland reduction conducted in pinyon, juniper, 
or pinyon-juniper mixed woodland types. The studies were distributed across a geographically extensive region and likely varied in tree species composition (i.e. were composed of different pinyon and/or juniper species) and in tree species dominance. We expect that our findings will vary by heterogeneity in the structure and species composition of the different woodland types included in this review. However, our synthesis did not include this extra level of heterogeneity because many authors did not provide adequate descriptions of the vegetation composition and tree dominance patterns at their study sites, making it difficult for us to reliably and consistently classify the woodland types associated with each study. Thus, we were unable to evaluate how animal responses varied by different woodland types across all studies.

Thirty-seven studies identified from our search (Appendix A) were evaluated to determine if they met our inclusion criteria. We only included studies that tested for significant differences between treatments and controls; thus eight studies were excluded because we were not able to extract significant effects from these studies (Appendix B). The results of these studies, however, are incorporated into the discussion of our findings. We also only included results from studies that directly tested the effects of woodland reduction treatments on one or more animal species by comparing treatment and control groups, pre- and post-treatment groups, or both; thus three studies were excluded that did not compare treatments to controls, but only measured wildlife use of treated areas without a control comparison (Appendix B). Most investigators only evaluated post-treatment wildlife responses, so the pre-treatment data reported in only a few studies were excluded to maintain consistency among studies. Furthermore, one study was excluded that compared wildlife use of treatments to multiple habitats (aspen, conifer, and pinyon-juniper) simultaneously, so the effects of pinyon or juniper reduction alone could not be assessed. We only included articles that reported original data; thus, one government report 
was excluded that duplicated data from a peer-reviewed journal article. We also only included results from studies that have been published in a government report, a conference proceedings, or a peer-reviewed journal; thus one study was excluded that presented preliminary results only, and one unpublished M.S. thesis was excluded. We only used studies that included primary data collection, thus one study that discussed potential effects on wildlife based on habitat requirements but did not provide direct empirical evidence was excluded. Lastly, we only included results from studies that compared species abundances/densities (or abundance indices, e.g. pellet counts) between treatment and control plots because the majority of studies that met our other selection criteria reported abundance-based responses only. Only two usable studies included non-abundance response metrics, such as survival and body condition, and these responses were excluded from our analysis because we could not report trends from only two studies (Appendix B). We excluded most of the above studies because they did not provide direct empirical evidence to address our specific research questions. This approach is consistent with the increasing recognition of the importance of conducting systematic reviews that are selective for, or place emphasis on, quality evidence, such as evidence drawn from experiments with true treatments and controls (Sutherland et al. 2004, Pullin and Stewart 2006).

We extracted data from the 19 studies that met our selection criteria by reviewing each paper for the following information: species studied, taxonomic group(s) studied, treatment type(s) studied (Table 1), location of treatment(s), years since treatment, size of treatment(s), effect measured, treatment result, and control result. We tallied all results to determine the relative proportions of positive, negative, and non-significant responses by different taxonomic groups and functional groups (see Appendix $\mathrm{C}$ for functional group classification). We define a result as one data point representing the difference between the treatment and the control 
(treatment - control) abundance metric for one species, one treatment method, and one sampling period. Since some studies investigated multiple species, treatment methods, and/or years, a single study can represent $>1$ data points (i.e. results) in our dataset. Results can either be positive (treatment metric > control metric and found to be significant in the study), negative (control metric > treatment metric and found to be significant in the study), or non-significant. We were not able to use these data to conduct a formal meta-analysis, because many investigators did not report the basic summary statistics (means, sample sizes, and variances for control and treatment groups) required for a meta-analysis (Haddaway 2015). 
Table 1. Treatment types evaluated in studies of wildlife responses to pinyon and juniper woodland reduction. Several treatment types were pooled into broader treatment categories for analysis. Some studies listed here were excluded from our analysis (see literature review methodology in section 4.1 for a discussion of our selection process and Appendix B for a list of used and excluded studies).

\begin{tabular}{|c|c|c|c|}
\hline Treatment type & $\begin{array}{l}\text { Broader } \\
\text { treatment type }\end{array}$ & Definition & $\begin{array}{l}\text { Studies that evaluated effects } \\
\text { of this method on wildlife }\end{array}$ \\
\hline Bulldozing & $\begin{array}{l}\text { Mechanical } \\
\text { removal }\end{array}$ & $\begin{array}{l}\text { Complete tree removal with } \\
\text { bulldozers. Woody debris may/may } \\
\text { not be removed. }\end{array}$ & $\begin{array}{l}\text { Turkowski and Reynolds } 1970 \text {, } \\
\text { Turkowski and Watkins } 1976, \\
\text { Short et al. } 1977, \text { Kruse et al. } \\
\text { 1979, Severson } 1986\end{array}$ \\
\hline Burning & NA & $\begin{array}{l}\text { Partial or full tree removal with } \\
\text { prescribed fire. Woody debris often } \\
\text { burned. }\end{array}$ & $\begin{array}{l}\text { Smith and Urness 1984, } \\
\text { Severson 1986, Smith et al. } \\
\text { 1999, Jehle et al. 2006, } \\
\text { Montblanc et al. 2007, Radke et } \\
\text { al. 2008, Higgins et al. 2014, } \\
\text { Knick et al. 2014, McIver and } \\
\text { Macke 2014, Ranglack and du } \\
\text { Toit } 2015\end{array}$ \\
\hline Chaining & $\begin{array}{l}\text { Mechanical } \\
\text { removal }\end{array}$ & $\begin{array}{l}\text { Complete tree removal. A boat anchor } \\
\text { chain attached between two } \\
\text { bulldozers is dragged across a wooded } \\
\text { area, uprooting and killing mature } \\
\text { trees. Woody debris may/may not be } \\
\text { removed. }\end{array}$ & $\begin{array}{l}\text { Baker and Frischknecht } 1973 \text {, } \\
\text { O'Meara et al. 1981, Howard et } \\
\text { al. 1987, Sedgwick and Ryder } \\
\text { 1987, Barnitz et al. 1990, } \\
\text { Tausch and Tueller 1995, } \\
\text { Ranglack and du Toit 2015, } \\
\text { Sandford and Messmer 2015 }\end{array}$ \\
\hline Cutting/mowing & $\begin{array}{l}\text { Mechanical } \\
\text { removal }\end{array}$ & $\begin{array}{l}\text { Complete tree removal. Trees hand- } \\
\text { cut with chainsaws and sometimes } \\
\text { further masticated with a rotary } \\
\text { mower. Mowers can also be used to } \\
\text { shred trees without cutting first. } \\
\text { Woody debris may/may not be } \\
\text { removed. }\end{array}$ & $\begin{array}{l}\text { Commons et al. 1999, Willis } \\
\text { and Miller 1999, Kleintjes et al. } \\
\text { 2004, Sabol 2005, Frey et al. } \\
\text { 2013, McIver and Macke } 2014\end{array}$ \\
\hline Hydro-ax & $\begin{array}{l}\text { Mechanical } \\
\text { removal }\end{array}$ & $\begin{array}{l}\text { Complete tree removal. Trees fully } \\
\text { masticated to woodchips using an } \\
\text { articulating mower. Woodchips often } \\
\text { left on ground. }\end{array}$ & $\begin{array}{l}\text { Bergman et al. } 2014^{\mathrm{a}} \text {, Reemts } \\
\text { and Cimprich } 2014 \text {, Bergman et } \\
\text { al. } 2015^{\mathrm{a}}\end{array}$ \\
\hline Roller-chop & $\begin{array}{l}\text { Mechanical } \\
\text { removal }\end{array}$ & $\begin{array}{l}\text { Complete tree removal. Trees crushed } \\
\text { with a bulldozer and an attached } \\
\text { large, water-filled drum with blades } \\
\text { that further chop woody debris and } \\
\text { disturb soil. Woody debris may/may } \\
\text { not be removed. }\end{array}$ & $\begin{array}{l}\text { Bergman et al. } 2014^{\text {a }} \text {, Bergman } \\
\text { et al. } 2015^{\text {a }}\end{array}$ \\
\hline
\end{tabular}




\begin{tabular}{|c|c|c|c|}
\hline $\begin{array}{l}\text { Partial } \\
\text { mechanical } \\
\text { removal/thinning }\end{array}$ & NA & $\begin{array}{l}\text { Partial tree removal by any of the } \\
\text { mechanical methods described here. } \\
\text { Woody debris may/may not be } \\
\text { removed. }\end{array}$ & $\begin{array}{l}\text { Kundaeli and Reynolds 1972, } \\
\text { Turkowski and Watkins 1976, } \\
\text { Short et al. 1977, Severson } \\
\text { 1986, Albert et al. 1994, Kruse } \\
\text { 1994, Crow and van Riper 2010, } \\
\text { Bender et al. } 2013\end{array}$ \\
\hline Uprooting & $\begin{array}{l}\text { Mechanical } \\
\text { removal }\end{array}$ & $\begin{array}{l}\text { Complete tree removal. Uprooting } \\
\text { method not well-described in study. }\end{array}$ & Kundaeli and Reynolds 1972 \\
\hline $\begin{array}{l}\text { Mechanical } \\
\text { removal and } \\
\text { burning }\end{array}$ & NA & $\begin{array}{l}\text { Trees removed using any mechanical } \\
\text { removal method and then burned } \\
\text { using prescribed fire. Woody debris } \\
\text { often destroyed by fire. }\end{array}$ & $\begin{array}{l}\text { Kundaeli and Reynolds 1972, } \\
\text { Turkowski and Watkins 1976, } \\
\text { Scott and Boeker 1977, Short et } \\
\text { al. } 1977\end{array}$ \\
\hline
\end{tabular}

${ }^{a}$ treatments also included herbicide applications

\subsection{Results and Discussion}

We found no consistent positive or negative trend on the effects of pinyon and juniper woodland reduction on wildlife. The majority of studies in our dataset did not detect significant differences in animal species abundance between woodland reduction treatment plots and control plots; however, we identified more frequent positive and negative responses to woodland reduction for particular taxonomic groups, treatments, and functional groups (Fig. 1, Fig. 2). We synthesize and discuss our findings below by taxonomic group, while highlighting additional variation in responses by treatment type, functional groups, and temporal and spatial scales. 


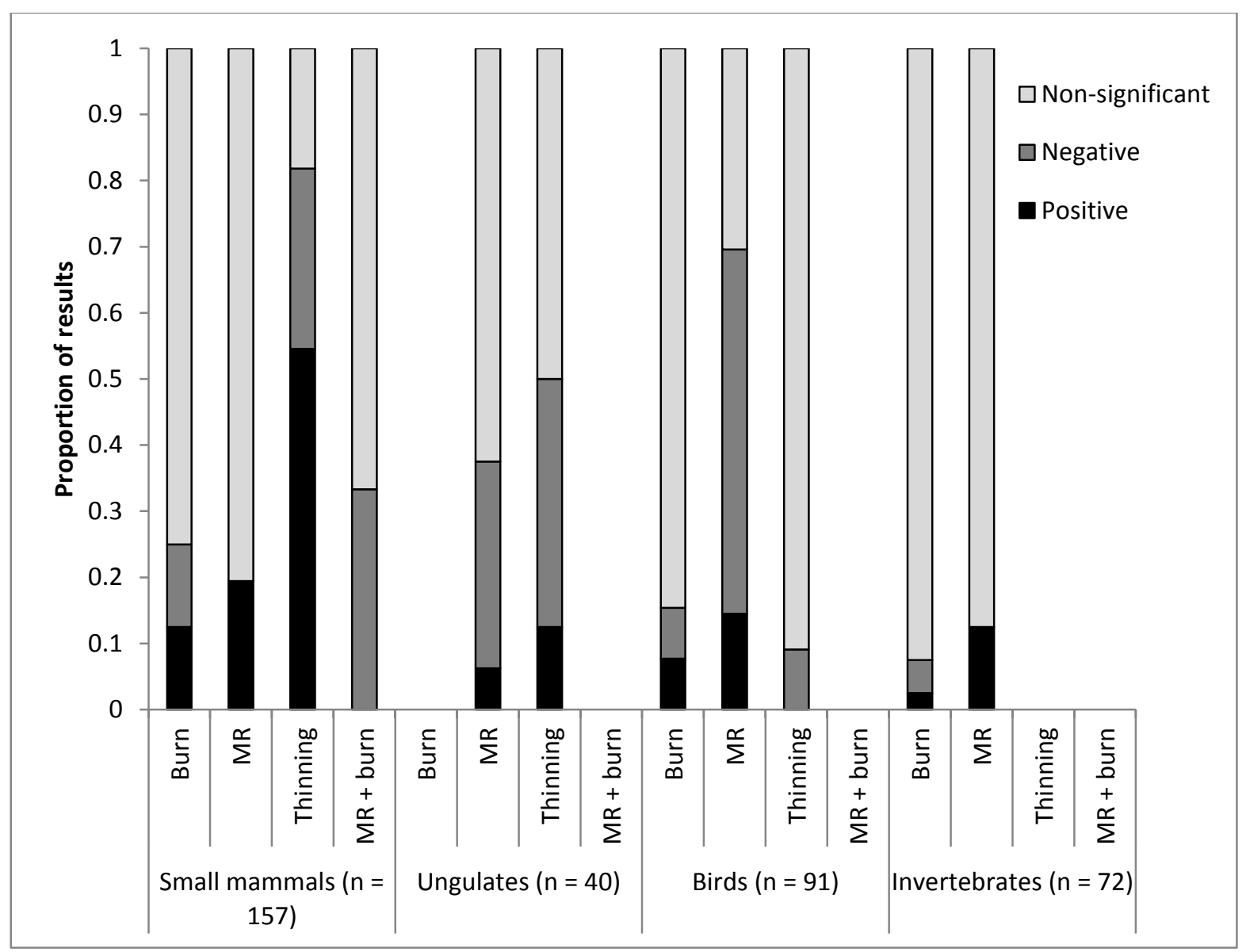

Fig. 1. Proportion of study results within taxonomic groups and treatment methods documenting positive, negative, or non-significant responses to woodland reduction. Burn $=$ prescribed fire; $M R=$ mechanical removal (i.e., bulldozing, chaining, cutting, mowing, hydroaxing, roller-chopping, and uprooting); Thinning = any treatment method that retains some standing trees; MR+burn = mechanical removal and prescribed fire . 


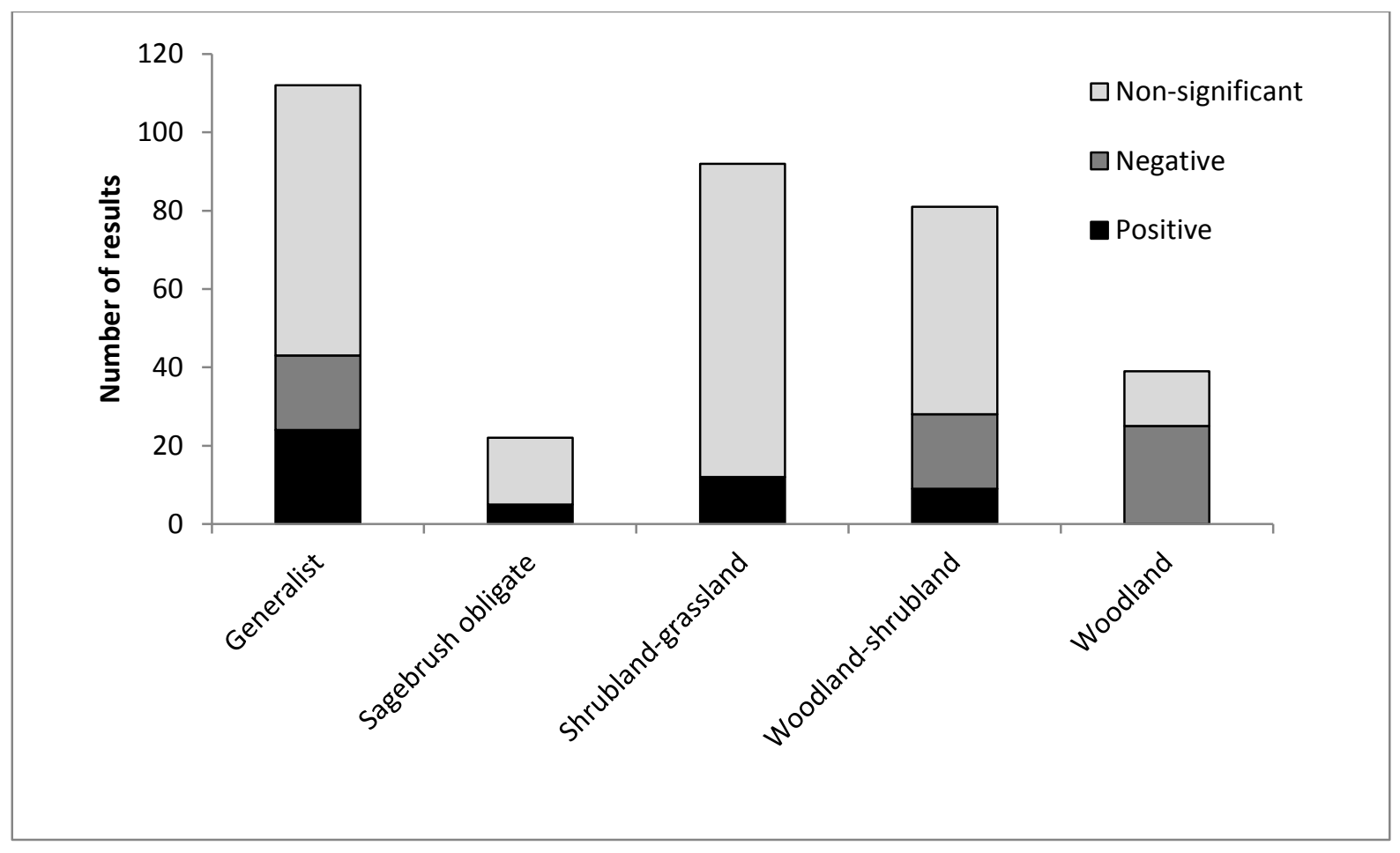

Fig. 2. Number of study results within habitat functional groups documenting positive, negative, or non-significant responses to woodland reduction treatments.

\subsubsection{Small Mammals}

Small mammal responses to woodland reduction varied considerably by treatment type. A larger proportion of studies on this group indicated positive responses of small mammals to thinning, but small mammals rarely responded positively to treatments that involved complete removal of trees (Fig 1). Thinning may be particularly attractive to many small mammal species because this treatment strategy increases understory slash cover while maintaining some existing overstory tree cover. Several investigators have found positive responses of many small mammal species to slash cover, including deer mice (Peromyscus maniculatus), voles (Microtus spp.) (Baker and Frischknecht 1973), woodrats (Neotoma spp.) (Turkowski and Reynolds 1970, Turkowski and Watkins 1976), pinyon mice, and rock mice (Chaetodipus intermedius) 
(Severson 1986). The combination of increased slash alongside retained overstory cover may be attractive to woodland species, e.g. pinyon mice and rock mice, that otherwise would respond negatively to woodland reduction treatment methods involving complete removal of trees (Severson 1986). Thus, thinning may be particularly beneficial to multiple small mammal species because it provides desirable habitat both for woodland species and for generalist species that are attracted to increased slash cover, irrespective of overstory cover.

An important exception to this pattern is grassland small mammal species. Severson (1986) found that pooled grassland species abundance was low on both control and thinned plots, but was significantly higher in bulldozed plots, suggesting that complete tree removal is needed to improve habitat for grassland small mammals. They attributed higher grassland species abundance to more extensive herbaceous cover found on bulldozed plots than on thinned or untreated plots (Severson 1986). Thus, land managers tasked with choosing among treatment methods should be aware of how different methods will affect various small mammal functional groups. Collectively, previous research suggests that thinning often increases, or does not adversely affect, the abundance of woodland and generalist species. However, methods that completely remove overstory cover often increase grassland species abundance. These trends were also reflected in the number of positive, negative, and non-significant results by functional group (Fig. 2), since generalist species like deer mice (O’Meara et al. 1981; Kruse 1994), whitethroated woodrats (Neotoma albigula; Severson 1986), and brush mice (Peromyscus boylii; Severson 1986), along with shrubland-grassland species, such as montane voles (Microtus montanus) and western harvest mice (Reithrodontomys megalotis; Smith and Urnress 1984) comprise many of the positive responses within these functional groups. 
Aside from the mostly positive responses to thinning and the occasional negative responses to mechanical removal, the majority of studies did not find significant responses by small mammals to any woodland reduction treatment method (Fig 1). However, several studies not included in these results found that total small mammal abundance increased substantially after woodland removal (Turkowski and Reynolds 1970, Baker and Frischknecht 1973, O’Meara et al. 1981, Albert et al. 1994); however these investigators did not test for significant differences in individual species abundances between treatment or control plots, and did not provide any statistical measures (i.e., variance or sample size) to facilitate comparisons. Also many authors that found greater total small mammal abundance on treatment plots than control plots noted that a significant proportion of the individuals caught were deer mice (O'Meara et al. 1981, Sedgwick and Ryder 1987, Albert et al. 1994, Kruse 1994). For example, deer mice comprised $85 \%$ of the total species caught in chained plots in a Colorado study (Sedgwick and Ryder 1987), and the authors concluded that the only species that benefitted from chaining was the deer mouse.

\subsubsection{Ungulates}

Ungulate responses to woodland reduction were only evaluated for mechanical removal and thinning treatment types, and the proportions of negative, positive and non-significant results were similar amongst these two treatment types (Fig 1). In spite of the fact that woodland reduction is often used to improve habitat for ungulates, most investigators found either nonsignificant or negative responses to tree removal by mule deer and elk (Fig 1). These responses may be explained by factors that affect treatment patch attractiveness to ungulates. For example, Howard et al. (1987) found that mule deer used chained areas more than control areas only during spring when forage was higher in the disturbed treatment patches. Also, Short et al. 
(1977) studied mule deer and elk use of pinyon and juniper woodlands cleared with bulldozers and chainsaws, and found that although large-scale clearings increased forage production, they were not attractive to deer or elk due to the loss of protective cover. However, smaller woodland reduction patches that existed within a matrix of protective cover were used more by deer and elk (Short et al. 1977). Thus, Short et al. (1977) recommend reducing pinyon and juniper woodlands in numerous small patches within a matrix of dense woodlands. Also, abundance or density metrics may be insufficient to detect differences in ungulate responses to treatments. Bergman et al. (2015) did not find differences in deer densities between control and woodland reduction treatment plots, but Bergman et al. (2014) found higher overwinter survival of mule deer fawns on treatment areas where plots were cleared, reseeded, and maintained with weed control. Thus Begman et al. (2015) recommend that multiple population metrics be used simultaneously to assess mule deer responses to woodland reduction.

\subsubsection{Birds}

Previous research generally indicates non-significant responses of birds to burning and thinning, yet bird responses to mechanical removal woodland reduction methods were often negative (Fig. 1). We considered mechanical removal to be complete tree removal by any mechanical means (Table 1). Thus, the cumulative findings from previous research indicate that treatments involving full mechanical removal of trees are often associated with reduced abundance of most bird species. However, burning and thinning treatments often do not result in complete tree removal (Table 1), and these treatment methods do not appear to strongly affect most bird species. Thus, treatment methods that leave interspersed standing trees may be more beneficial for birds than those that eliminate all trees. 
Several authors have emphasized the need to maintain tree cover to support pinyon and juniper woodland birds. Pavlacky and Anderson (2001) investigated habitat associations for pinyon and juniper obligate birds and found that most of these species favored areas with greater pinyon pine cover and high canopy height; they conclude that maintaining pinyon pine is critical to providing quality habitat for pinyon-juniper specialists. Balda and Masters (1980) also stress retaining pinyon pines because they detected a positive relationship between foliage-feeding and/or cavity nesting birds and pinyon pine density. Francis et al. (2011) found that $86 \%$ of nests in live trees that belonged to open cup and cavity nesting birds occurred in juniper trees, and recommended that the selective removal of juniper be avoided when thinning woodlands.

In contrast to our overall non-significant findings, several investigators have found reduced numbers of many bird species, particularly birds that commonly use woodland habitat, in woodland reduction plots treated with chaining, thinning, and burning compared to untreated control plots (Kruse et al. 1979, O’Meara et al. 1981, Sedgwick and Ryder 1987, Albert et al. 1994). Yet, most of these studies did not test for significant differences in bird species abundance between treatments and controls (Kruse et al. 1979, O’Meara et al. 1981, Albert et al. 1994), and were thus not included in our analysis. Because these investigators did not apply statistical tests or provide measures of uncertainty, we cannot evaluate how these findings relate to those included in our analysis. Sedgwick and Ryder (1987) tested for differences and found lower total bird abundance, and lower abundance of 11 of 16 species on chained plots compared with untreated control plots. They also found that several woodland-associated bird guilds (i.e. foliage and timber searchers, aerial foragers, and cavity nesters) used chained plots significantly less (Sedgwick and Ryder 1987). Although O’Meara and others (1981) did not test for differences between individual species, the authors did analyze differences among bird functional groups, 
and similarly found that woodland-associated functional groups had lower total abundance on chained plots than on unchained plots. Crow and Van Riper (2010) found that two woodlandassociated birds, the Gray vireo (Vireo vicinior) and the Chipping sparrow (Spizella passerine) did not occur or were significantly reduced in abundance on plots treated with thinning, however most bird species in their study did not significantly respond positively or negatively to thinning treatments. Given these cumulative findings, it should not be surprising that woodland birds also comprised the majority of negative responses identified for the woodland functional group in our study (Fig. 2).

In spite of the expectation that sagebrush birds would increase in areas treated with woodland removal, there is limited evidence to support this assumption since most bird responses to woodland reduction were either non-significant or negative (Fig 1). For example, Sedgwick and Ryder (1987) found that use of control and chaining treatment plots did not significantly differ for functional groups associated with grasslands and shrublands (i.e. ground foragers and ground nesters). Similarly, Knick et al. (2014) did not find significant differences between burning and control treatments for most sagebrush specialists. Furthermore, only a small number of positive results were found for sagebrush obligate species in general (Fig. 2). These results are unexpected because the link between woodland expansion and loss of sagebrush habitat for sagebrush obligate species, especially the greater sage-grouse (Centrocercus urophasianus), is well established (Rowland et al. 2006, Casazza et al. 2011, Knick et al. 2013, Baruch-Mordo et al. 2013). Thus, it should follow that woodland reduction would improve habitat for sagebrush obligates, and that we would find a large proportion of positive responses to woodland reduction practices for this functional group. Instead, positive responses have only been documented for a few bird species. Crow and Van Riper (2010) detected a positive 
response to thinning by the sagebrush specialist Brewer's sparrow (Spizella breweri).

Furthermore, Frey et al. (2013) found higher use of treatment areas one year post-treatment by another sagebrush specialist, the greater sage grouse, and the abundance of male sage grouse on leks doubled after the removal of young junipers that had invaded sage-steppe habitat (Commons et al. 1999).

Although there has been limited evidence of positive responses to woodland reduction by many sagebrush obligate birds, the effects of tree removal on most of these species has not been well-studied. Only three studies tested for significant differences in sagebrush obligate bird species abundance between woodland reduction treatment and control areas (Crow and Van Riper 2010, Frey et al. 2013, Knick et al. 2014). Even greater sage grouse responses to woodland reduction have rarely been rigorously tested (but see Frey et al. 2013). Since the Sage Grouse Initiative plans to invest $\$ 211$ million in coming years to improve habitat for sage grouse through woodland reduction and other means (Natural Resources Conservation Service 2015), many more studies may emerge on the consequences of woodland reduction practices for greater sage grouse and other sagebrush obligate species. These findings may help determine whether the largely non-significant responses reported thus far for sagebrush obligates reflect generalized patterns among this functional group.

\subsubsection{Invertebrates}

Given the diversity of invertebrate taxonomic groups found in pinyon and juniper woodlands (Frischknecht 1975, Brantley and Shepherd 2004), we expected that invertebrate responses to woodland reduction would be highly variable. Yet, most investigators previously found non-significant responses to woodland reduction treatments by invertebrates (Fig. 1). These studies focused primarily on lepidopteran species (Kleintjes et al. 2004, McIver and 
Macke 2014), but responses by ants (Montblanc et al. 2007), and 16 other taxonomic orders were investigated by Radke et al. (2008). Most of the significant positive or negative responses were found for lepidopterans, however. McIver and Macke (2014) found increased abundance after burning or mechanical removal treatments for Melissa blues (Plebejus melissa) and sulfurs (Colias spp.), but detected declines in the abundance of juniper hairstreaks (Callophrys gryneus), a species that depends on juniper vegetation for food in the larval stage. Also, Kleintjes et al. (2004) found that butterfly richness and abundance was positively associated with increased forb cover found in cut and slash treatment areas, and an associated increase in nectar, oviposition sites, and forage availability. Although the sample size of studies for all taxonomic groups was relatively small, studies focused on invertebrates were particularly scarce (Kleintjes et al. 2004, Montblanc et al. 2007, Radke et al. 2008, McIver and Macke 2014), and these studies were limited to burning and mechanical removal treatment methods (Fig. 1). Thus, we cannot say with confidence whether the largely non-significant effects of woodland reduction on invertebrate abundance are generalizable, and we encourage caution in interpreting these findings.

\subsubsection{Future Research Priorities}

Through our review of the literature, we have identified several important knowledge gaps, which could inhibit evidence-based management of pinyon and juniper woodlands. We urge investigators to prioritize the following research directions to enhance understanding of the effects of woodland reduction on wildlife.

First, we have identified a critical lack of information on the responses of many animal assemblages to pinyon and juniper woodland reduction. Small mammal and ungulate responses have been evaluated frequently across most treatment strategies, and bird responses have been 
moderately studied across all treatment strategies (Fig. 3). However, invertebrate and reptile responses to woodland reduction have rarely been investigated for all but burning treatments, and responses of other taxonomic groups (e.g. amphibians, bats, and large predators) have not been examined (Fig. 3). Prioritizing under-studied taxa in future research would broaden our understanding of wildlife responses to woodland reduction and help land managers make informed decisions about the potential synergies and tradeoffs of woodland reduction for nontargeted animal species.

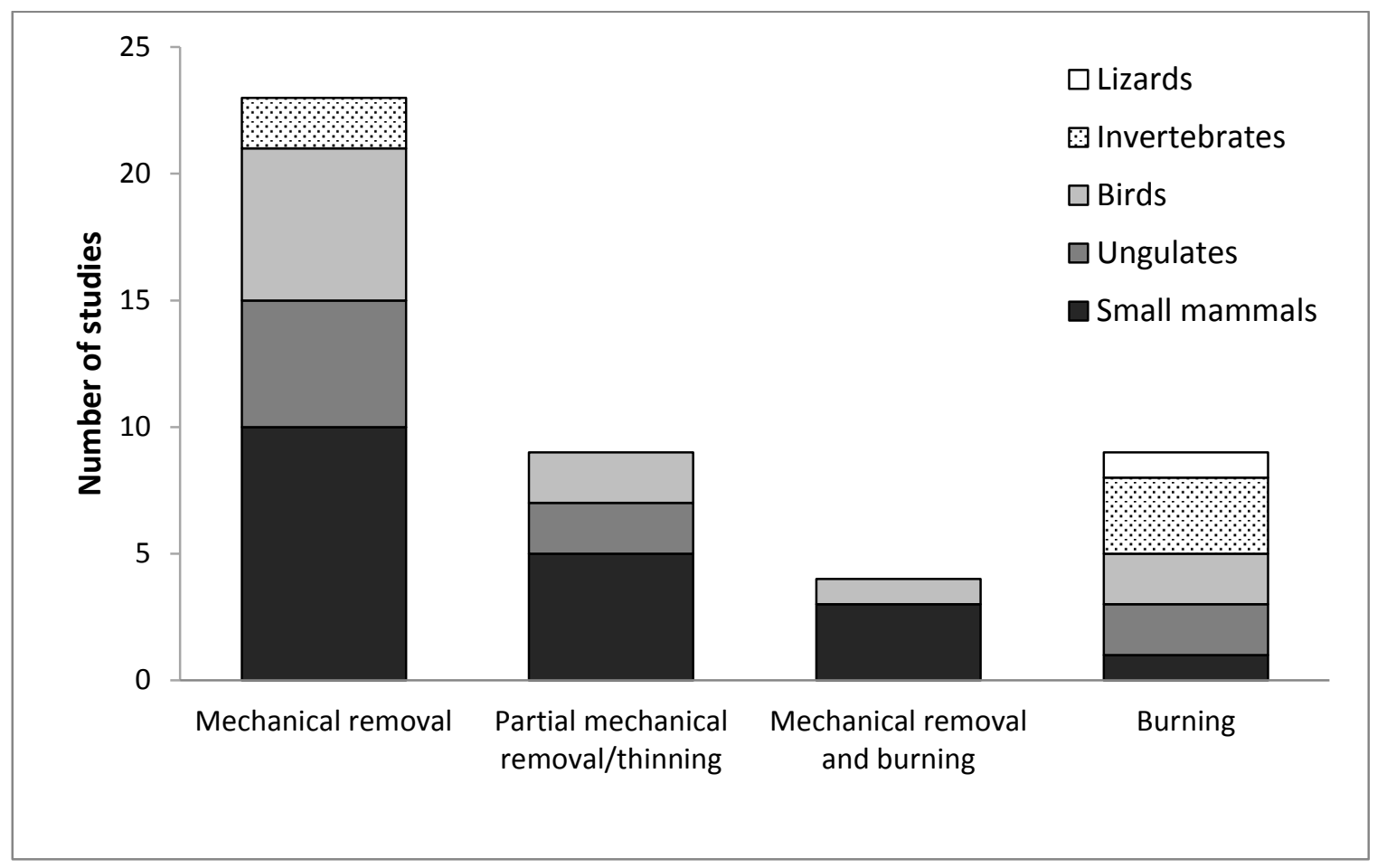

Fig. 3. Number of studies conducted on wildlife responses to pinyon and juniper woodland reduction strategies, by taxonomic group and by treatment type. Mechanical removal = bulldozing, chaining, cutting, mowing, hydro-axing, roller-chopping, and uprooting. Some studies investigated multiple woodland reduction methods and/or taxonomic groups simultaneously and thus are represented with more than one data point. 
Second, we lack sufficient empirical evidence on the effects of certain woodland reduction treatment methods on wildlife. Previous literature has focused primarily on bulldozing, chaining, thinning, and burning (Table 1). Land managers in western North America are currently employing alternate mechanical woodland reduction methods, e.g. hydro-axing and roller-chopping, along with traditional methods, to enhance habitat quality for sage grouse, cattle, and ungulate species (Pyke 2011, Bergman et al. 2014). Yet, the effects of these newer methods on wildlife have been given minimal attention (Table 1), and non-ungulate species responses to these methods have not been evaluated. Future research should simultaneously evaluate the effects of novel and traditional woodland reduction methods on wildlife so that we can gain a better understanding of the comparative effects of different treatment methods, and identify treatments that provide more benefits and fewer costs to non-targeted wildlife populations.

Third, there is insufficient information to understand long-term and large-scale responses to woodland reduction for most taxonomic groups and treatment methods. The majority of studies evaluated wildlife responses to woodland reduction within 1-10 years post-treatment $(86 \%)$ (Fig. 4) and in treatment plots under 100 hectares (52\%) (Fig. 5).

Furthermore, the distribution of the few long-term studies is not balanced among taxonomic groups. Ungulates, small mammals, and birds were studied over the greatest range of years (1-55, 1-32, and 1-25 years post-treatment, respectively); whereas reptiles and invertebrates were studied for up to only one and five years post-treatment, respectively (Fig. 4). Since vegetation and substrate conditions will likely differ between early and later successional stages, longer-term studies on underrepresented taxonomic groups are necessary to fully understand wildlife responses to woodland reduction. 
Long-term effects may be particularly important to consider for sagebrush obligate species. Positive responses by these species to woodland reduction may not occur until long after treatments are completed, when the shrub community has had time to regenerate. Indeed, a modeling study predicted that sage grouse habitat will not improve until over 20 years after burning treatments were applied, when sagebrush cover has reestablished (Arkle et al. 2014). If this is the case for other sagebrush obligates, our review is unlikely to have detected this outcome because previous studies of sagebrush obligate species rarely measured long-term responses. Only one study rigorously evaluated long-term (32 years post-treatment) responses for the sagebrush vole (Smith and Urness 1984). All other studies focused on sagebrush obligate bird responses, and occurred within 1-5 years post-treatment (Crow and Van Riper 2010, Frey et al. 2013, Knick et al. 2014). Two long-term (> 15 year post-treatment) studies included sagebrush obligate and shrubland-grassland species (Kruse et al. 1979, O'Meara et al 1981), but these studies only reported count data and did not statistically compare individual species abundances between treatments and controls, so they were not included in our analysis. However, they did report higher counts on $>15$ year old woodland reduction treatment plots for one sagebrush obligate species (Brewer's sparrow Spizella breweri) and several shrublandgrassland species (Green-tailed towhee Pipilo chlorura, Vesper sparrow Pooecetes gramineus, Horned lark Eremophila alpestris, Eastern meadowlark Sturnella magna, and Western meadowlark Sturnella neglecta).Woodland management actions are often taken under the assumption that tree removal will benefit sagebrush obligate species, but we currently lack strong empirical evidence to support this assumption. Thus, it is imperative that future research is conducted to evaluate long-term responses to woodland reduction by sagebrush obligates. 

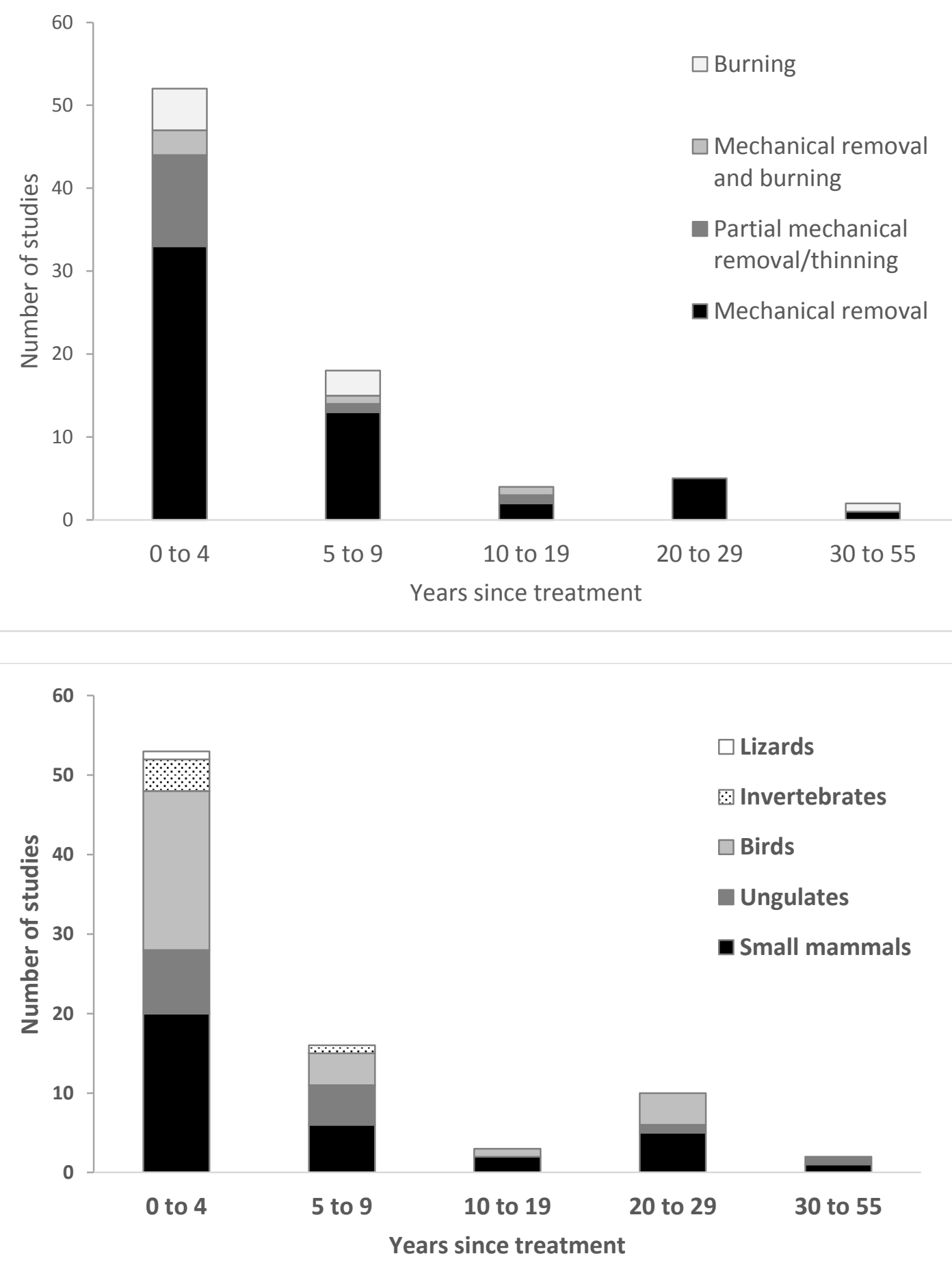

Fig. 4. Temporal distribution of studies investigating wildlife responses to pinyon and juniper woodland reduction strategies, by treatment type (top) and by taxonomic group (bottom). 
Mechanical removal $=$ bulldozing, chaining, cutting, hydro-axing, roller-chopping, and uprooting. Some studies investigated multiple woodland reduction methods and/or taxonomic groups simultaneously and thus are represented with more than one data point. 

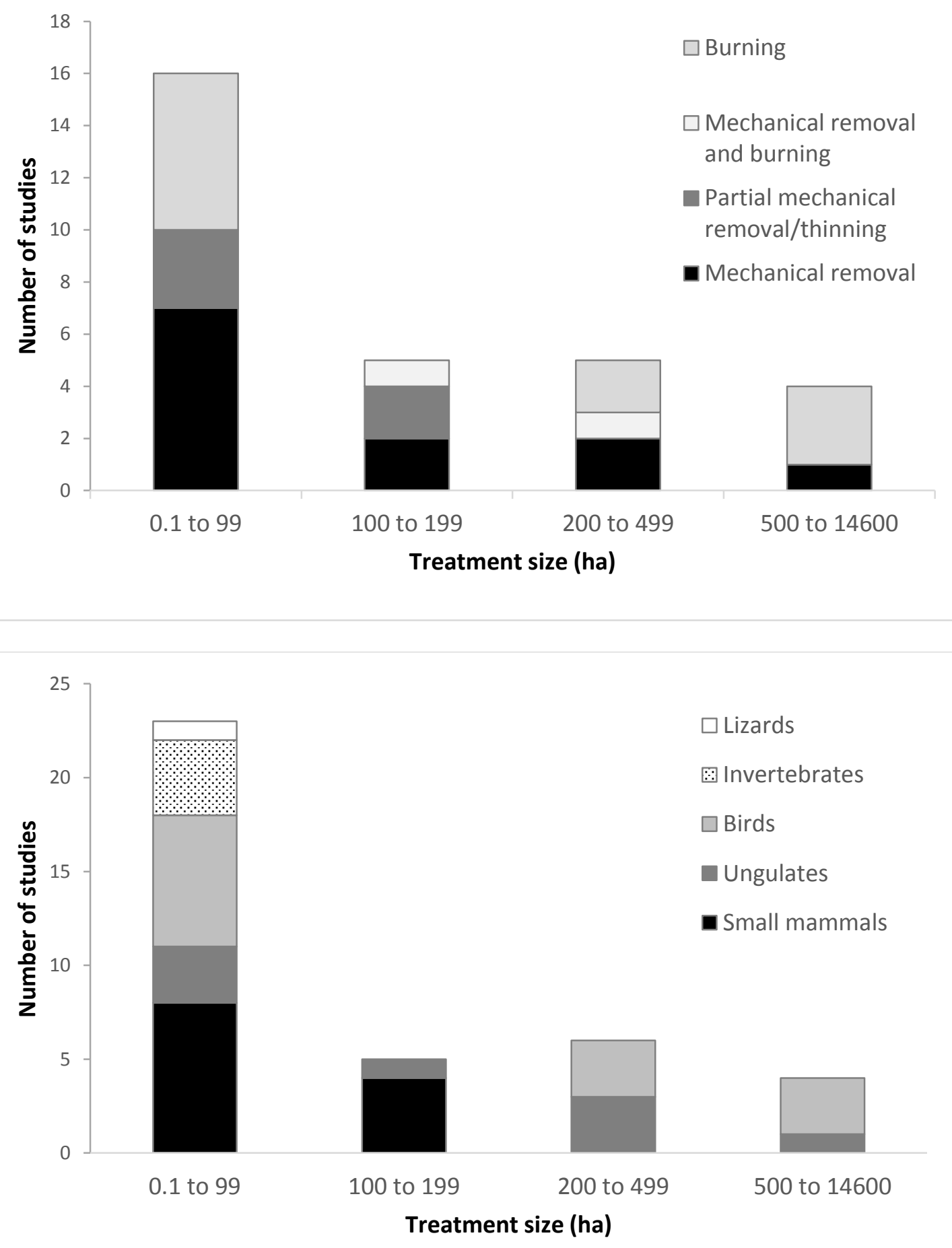

Fig. 5. Spatial extent of studies investigating wildlife responses to pinyon and juniper woodland reduction methods, by treatment type (top) and by taxonomic group (bottom). 
Mechanical removal $=$ bulldozing, chaining, cutting, hydro-axing, roller-chopping, and uprooting. Some studies investigated multiple woodland reduction methods and/or taxonomic groups simultaneously and thus are represented by more than one data point.

The distribution of large-scale studies is also not balanced among taxonomic groups. Large-scale studies were biased towards ungulates and birds, which were often studied in larger treatment plots (200 to $14600 \mathrm{ha}$ ); whereas treatment plots under 200 ha were often used to study small mammal, invertebrate, and lizard responses to woodland reduction (Fig. 5). These scales may appropriately reflect the home range size of animals in each taxonomic group; however small plots are subject to greater edge effects. Thus the response of smaller animals to the interior core conditions of larger treatments might not be captured in these findings. Research that evaluates the response of small animal species to larger woodland reduction treatments - or even better - evaluates small animal responses at multiple scales simultaneously, would add much to the literature.

Long-term and large-scale studies are also unbalanced amongst different treatment methods. Mechanical removal treatments covered the greatest range of years (1-55 years posttreatment; mean $=6.8$ years $)$, followed by burning treatments $(1-32$ years post-treatment; mean $=$ 6.9 years); but thinning treatments and mechanical removal + burning treatments were only studied out to 15 years post-treatment (mean $=3.5$ years and 6.2 years, respectively) (Fig. 4). If different treatment methods result in different long-term successional patterns; the effects of thinning and mechanical removal + burning treatments on wildlife may have gone undetected. With respect to scale, most treatments methods have been studied in plots under 500 hectares, but burning has been the primary method investigated in larger-scale treatments (Fig. 5). Thus, 
the effects on wildlife from large-scale thinning and mechanical removal, with or without burning, deserve more attention, especially if the vegetative changes associated with these different treatment methods are scale-dependent or subject to edge effects.

Finally, some geographic regions have received good coverage by previous research on the effects of woodland reduction on wildlife, whereas other regions are understudied (Fig. 6). Multiple studies have occurred in states with more extensive pinyon and juniper ranges, i.e., Arizona, Colorado, New Mexico, and Utah. However, wildlife responses to woodland reduction have rarely been evaluated in several U.S. states that also have considerable pinyon and/or juniper woodland coverage (e.g. Idaho, Wyoming, and California), or in other countries (Fig. 6). Thus, many species' responses to woodland reduction may have gone undetected, especially species that occupy a limited range or specialized habitat, such as inner coastal woodlands. Efforts to expand research into understudied western U.S. states, Canada, and Mexico would add value to the existing body of literature, by providing decision-makers with a more geographically extensive and context-specific understanding of the consequences of woodland reduction practices for a diversity of wildlife species. 


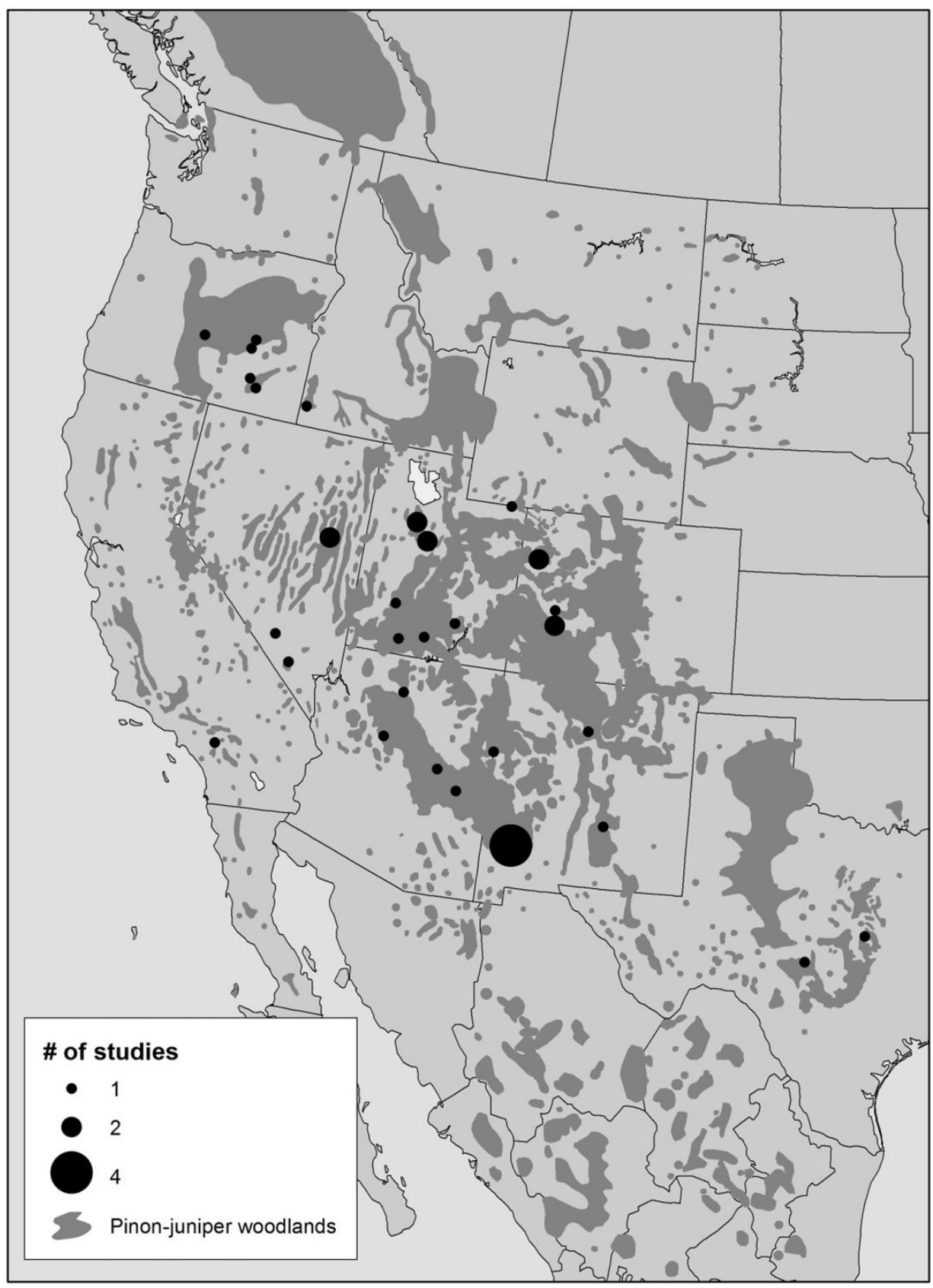

Fig. 6. Geographic distribution of studies investigating wildlife responses to pinyon and juniper woodland reduction strategies in North America. Pinyon and juniper woodland patches include pinyon and/or juniper trees at varying densities. Large-scale studies with replicates in several states (i.e. Knick et al. 2014, McIver and Macke 2014) are plotted multiple times with a point for each unique study location. 
Importantly, our review only included studies that measured abundance-based response metrics. Yet, abundance may not be a sufficient measure of habitat quality under certain circumstances, e.g. when habitat use varies seasonally, when the habitat is patchy, or when species are habitat generalists (Van Horne 1983). Ideally, inferences about habitat quality should be based on abundance values along with other demographic data, i.e. survival and offspring production (Van Horne 1983). However, the large majority of previous studies that evaluated wildlife responses to woodland reduction measured abundance-based responses; only two studies that met our selection criteria considered other response metrics. Thus, current literature limits our ability to determine whether the patterns of species abundance summarized in this review reflect true habitat quality, and we urge future investigators to measure multiple demographic parameters when evaluating species' responses to woodland reduction.

In summary, to address important knowledge gaps, investigators should concentrate their efforts on long-term (>10 years post-treatment) and large-scale (>100 ha plots) effects of several different woodland reduction strategies on different taxonomic groups, especially the understudied groups identified above. Positive and negative responses of different taxonomic groups to woodland reduction may vary by spatial and temporal scales, and by the treatment method used. Thus, long-term and large-scale studies across different treatment methods are needed for even frequently-studied taxonomic groups like birds, ungulates, and small mammals. Also, since some species' responses to woodland reduction may not be adequately represented in the existing literature because of a lack of geographic coverage, research in many understudied regions of the western U.S., Mexico, and Canada should be prioritized. Finally, investigators should measure abundance along with survival and reproduction response metrics so that the effects of woodland reduction on habitat quality can be more fully assessed (Van Horne 1983). 
The difficulty of incorporating long-term and large-scale studies across multiple treatment types, regions, and taxonomic groups might be eased if investigators coordinated evaluating these priorities across multiple projects. Thus, we encourage practitioners to adopt consistent monitoring protocols across projects and to develop a record-keeping system that requires, at minimum, reporting of important summary statistics (i.e. means, sample sizes, and variances for all control and treatment groups). These efforts would allow future findings to be more easily compared and/or incorporated into a meta-analysis across different regions and projects, which may increase our understanding of how factors such as treatment type, size, location, and duration result in positive or negative effects on diverse wildlife assemblages.

\subsection{WOODLAND REDUCTION STRATEGIES FOR MULTI-SPECIES CONSERVATION}

Finding ways to implement woodland reduction strategies that target multiple-species conservation objectives remains an important conservation challenge in one of the largest ecosystems in western North America. Woodland reduction will likely increase as pinyon and juniper expansion continues to threaten species of economic or conservation concern that are sensitive to conifer encroachment into sagebrush and grassland ecosystems. As it is unlikely that a single strategy will improve habitat for all species, managers need to make science-based decisions that acknowledge and reconcile costs and benefits to diverse wildlife from this form of habitat manipulation.

To this aim, we have identified likely 'winners' and 'losers' from our synthesis of the effects of woodland reduction on wildlife. As expected, woodland-affiliated species frequently responded negatively (significantly lower abundances in treatment plots than control plots) to woodland reduction (Fig. 2). Many of these species were woodland birds, which rarely exhibited 
negative responses to thinning or burning treatments (Fig. 1); thus woodland reduction methods that thin trees may have fewer negative impacts on woodland birds than those methods that remove all trees. Small mammals also frequently responded positively to thinning treatments, providing further evidence that thinning may generate fewer unintended negative consequences on non-targeted wildlife species compared with other woodland reduction methods. Grassland dependent small mammals were an exception; they tended to respond positively to full mechanical removal of trees, but not to thinning.

Contrary to our expectations, we did not find many positive responses to woodland reduction by sagebrush obligate and shrubland-grassland species. Yet, very few studies have evaluated sagebrush obligate species responses to woodland reduction, so additional research is needed to determine the generality of the few previous findings. Furthermore, most investigators considered short-term responses to woodland reduction only; whereas sagebrush obligate and shrubland-grassland species may not respond positively to treatments until several years posttreatment, when the early- to mid-successional shrub, herb, and grass community has been established (Arkle et al. 2014).

Given limited funding for conservation, land managers need science-based information on the consequences of woodland reduction for targeted and non-targeted species, so that resources can be allocated to maximize benefits and minimize undesirable outcomes. Surprisingly, most previous studies did not identify significant responses to woodland reduction for a diversity of animal species. These findings call in to question the general utility of this costly and time-intensive form of habitat manipulation. What is not clear however, is whether these largely non-significant responses represent a true non-response, or whether responses were measured over too short of a timeframe, or lacked statistical power to detect differences. Thus, 
we discourage readers from treating the frequent non-significant results as a generality until enough suitable data has emerged on this topic to conduct a meta-analysis, and we urge managers to prioritize the coordinated collection and analysis of these data. A better understanding of how traditional and novel woodland reduction strategies affect multiple taxonomic groups, especially poorly-studied reptile and invertebrate assemblages, at multiple spatial and temporal scales is vital for guiding decision-making in pinyon and juniper and sagesteppe landscapes. 


\subsection{ACKNOWLEDGEMENTS}

Many thanks to K. Wilson, M. Paschke and two anonymous reviewers for providing valuable comments that improved earlier drafts of this manuscript. This research was supported by funding from Exxon/XTO and the National Science Foundation Graduate Research Fellowship Program. 


\subsection{LITERATURE CITED}

Albert, S. K., N. Luna, and A. L. Chopito. 1994. Deer, small mammal, and songbird use of thinned pinon-juniper plots: preliminary results. in D. W. Shaw, E. F. Aldon, and C. LoSapio, editors. Desired future conditions for pinyon-juniper ecosystems, Flagstaff, AZ. USDA Forest Service Gen. Tech. Rep. RM-GTR-258, Fort Collins, CO.

Anderson, E. D., R. A. Long, M. P. Atwood, J. G. Kie, T. R. Thomas, P. Zager, and R. T. Bowyer. 2012. Winter resource selection by female mule deer Odocoileus hemionus : functional response to spatio-temporal changes in habitat. Wildlife Biology 18:153-163.

Arkle, R. S., D. S. Pilliod, S. E. Hanser, M. L. Brooks, J. C. Chambers, J. B. Grace, K. C. Knutson, D. A. Pyke, J. L. Welty, and T. A. Wirth. 2014. Quantifying restoration effectiveness using multi-scale habitat models: implications for sage-grouse in the Great Basin. Ecosphere 5:art31.

Aro, R. S. 1971. Evaluation of pinyon-juniper conversion to grassland. Journal of Range Management 24:188-197.

Baker, M. F., and N. C. Frischknecht. 1973. Small mammals increase on recently cleared and seeded juniper rangeland. Journal of Range Management 26:101-103.

Balda, R. P., and N. Masters. 1980. Avian communities in the pinyon-juniper woodland: a descriptive analysis. Pages 146-169 in R. M. DeGraff and N. G. Tilghman, editors. Proceedings: management of western forests and grasslands for nongame birds. USDA Forest Service Gen. Tech. Rep. INT-86, Ogden, Utah.

Barnitz, J., A., V. W. Howard, and G. M. Southward. 1990. Mule deer and rabbit use on areas of pinyon-juniper woodland treated by two-way cabling. 40 pages. New Mexico State University College of Agriculture and Home Economics, Las Cruces, New Mexico. 
Baruch-Mordo, S., J. S. Evans, J. P. Severson, D. E. Naugle, J. D. Maestas, J. M. Kiesecker, M. J. Falkowski, C. A. Hagen, and K. P. Reese. 2013. Saving sage-grouse from the trees: A proactive solution to reducing a key threat to a candidate species. Biological Conservation 167:233-241.

Belsky, A. J. 1996. Western juniper expansion: Is it a threat to arid northwestern ecosystems? Journal of Range Management 49:53-59.

Bender, L. C., L. A. Lomas, and T. Kamienski. 2007. Habitat effects on condition of doe mule deer in arid mixed woodland-grassland. Rangeland Ecology and Management 60:277-284.

Bender, L. C., R. A. Baldwin, and J. R. Piasecke. 2012. Habitats occupied by elk (Cervus elaphus) in desert grassland-scrublands of northwestern New Mexico. The Southwestern Naturalist 57:361-369.

Bender, L. C., J. C. Boren, H. Halbritter, and S. Cox. 2013. Effects of site characteristics, pinyon-juniper management, and precipitation on habitat quality for mule deer in New Mexico. Human-Wildlife Interactions 7:47-59.

Bergman, E. J., C. J. Bishop, D. J. Freddy, G. C. White, and P. F. Doherty. 2014. Habitat management influences overwinter survival of mule deer fawns in Colorado. The Journal of Wildlife Management 78:462-445.

Bergman, E. J., P. F. Doherty, G. C. White, and D. J. Freddy. 2015. Habitat and herbivore density: Response of mule deer to habitat management. The Journal of Wildlife Management 79:60-68.

Blackburn, W. H., and P. T. Tueller. 1970. Pinyon and juniper invasion in black sagebrush communities in East-Central Nevada. Ecology 51:841. 
Brantley, S. L., and U. L. Shepherd. 2004. Effect of cryptobiotic crust type on microarthropod assemblages in piñon-juniper woodland in central New Mexico. Western North American Naturalist 64:155-165.

Breshears, D. D., N. S. Cobb, P. M. Rich, K. P. Price, C. D. Allen, R. G. Balice, W. H. Romme, J. H. Kastens, M. L. Floyd, J. Belnap, J. J. Anderson, O. B. Myers, and C. W. Meyer. 2005. Regional vegetation die-off in response to global-change-type drought. Proceedings of the National Academy of Sciences 102:15144-15148.

Bristow, N. A., P. J. Weisberg, and R. J. Tausch. 2014. A 40-year record of tree establishment following chaining and prescribed fire treatments in singleleaf pinyon (Pinus monophylla) and Utah juniper ( Juniperus osteosperma ) woodlands. Rangeland Ecology \& Management 67:389-396.

Casazza, M. L., P. S. Coates, and C. T. Overton. 2011. Linking habitat selection and brood success in Greater Sage-Grouse. Pages 151-167 in B. K. Sandercock, K. Martin, and G. Segelbacher, editors. Ecology, Conservation, and Management of Grouse. University of California Press, Berkeley, California, USA.

Chung-MacCoubrey, A. L. 2005. Use of pinyon-juniper woodlands by bats in New Mexico. Forest Ecology and Management 204:209-220.

Commons, M. L., R. K. Baydack, and C. E. Braun. 1999. Sage grouse response to pinyon-juniper management. in S. B. Monsen and R. Stevens, editors. Proceedings: ecology and management of pinyon-juniper communities within the Interior West. USDA Forest Service Proceedings RMRS-P-9, Ogden, UT. 
Crow, C., and C. van Riper. 2010. Avian community responses to mechanical thinning of a pinyon-juniper woodland: specialist sensitivity to tree reduction. Natural Areas Journal 30:191-201.

DOI. 2013. Endangered and threatened wildlife and plants; endangered status for Gunnison sagegrouse Part II. Page 81. Federal Register, Department of the Interior.

Evans, R. A. 1988. Management of pinyon-juniper woodlands. USDA Forest Service Gen. Tech. Rep. INT-249, Ogden, UT. 34 pages.

Finch, D. M., and L. F. Ruggiero. 1993. Wildlife habitats and biological diversity in the Rocky Mountains and Northern Great Plains. Natural Areas Journal 13:191-203.

Floyd, M. L., M. Clifford, N. S. Cobb, D. Hanna, R. Delph, P. Ford, and D. Turner. 2009. Relationship of stand characteristics to drought-induced mortality in three Southwestern piñon-juniper woodlands. Ecological Applications 19:1223-1230.

Francis, C. D., C. P. Ortega, and J. Hansen. 2011. Importance of juniper to birds nesting in piñon-juniper woodlands in northwest New Mexico. The Journal of Wildlife Management 75:1574-1580.

Frey, S. N., R. Curtis, and K. Heaton. 2013. Response of a small population of greater sagegrouse to tree removal: implications of limiting factors. Human-Wildlife Interactions 7:260-272.

Frischknecht, N. C. 1975. Native faunal relationships within the pinyon-juniper ecosystem. Pages 55-65 in The pinyon-juniper ecosystem: A symposium. Utah State University, Logan Utah.

Gottfried, G. J., T. J. Setnam, C. D. Allen, J. L. Betancourt, and A. L. Chung-MacCoubrey. 1995. Pinyon-juniper woodlands. in D. M. Finch and Tainter, editors. Ecology, diversity 
and sustainability of the Middle Rio Grande Basin. USDA Forest Service Gen. Tech. Rep. RM-268, Fort Collins, CO.

Haddaway, N. R. 2015. A call for better reporting of conservation research data for use in metaanalyses: Improved reporting of results. Conservation Biology 29:1242-1245.

Higgins, J. W., N. S. Cobb, S. Sommer, R. J. Delph, and S. L. Brantley. 2014. Ground-dwelling arthropod responses to succession in a pinyon-juniper woodland. Ecosphere 5:1-29.

Hoenes, B. D., L. C. Bender, and D. Brock. 2012. Factors influencing foraging habitats of mule deer (Odocoileus hemionus) in the San Andres Mountains, New Mexico. The Southwestern Naturalist 57:370-379.

Howard, V. W., K. M. Cheap, R. H. Hier, T. G. Thompson, and J. A. Dimas. 1987. Effects of cabling pinyon-juniper on mule deer and lagomorph use. Wildlife Society Bulletin 15:242247.

Jehle, G., J. A. Savidge, and N. B. Kotliar. 2006. Green-tailed towhee response to prescribed fire in montane shrubland. The Condor 108:634.

Kleintjes, P., B. Jacobs, and S. Fettig. 2004. Initial response of butterflies to an overstory reduction and slash mulching treatment of a degraded pinon-juniper woodland. Restoration Ecology 12:231-238.

Knick, S. T., S. E. Hanser, and M. Leu. 2014. Ecological scale of bird community response to piñon-juniper removal. Rangeland Ecology and Management 67:553-562.

Knick, S. T., S. E. Hanser, and K. L. Preston. 2013. Modeling ecological minimum requirements for distribution of greater sage-grouse leks: implications for population connectivity across their western range, U.S.A. Ecology and Evolution 3:1539-1551. 
Koniak, S., and R. L. Everett. 1982. Seed reserves in soils of successional stages on pinyon woodlands. American Midland Naturalist 102:295-303.

Kruse, W. H. 1994. Effects of fuelwood harvesting on small mammal populations in a pinonjuniper woodland. Pages 91-96 in D. W. Shaw, E. F. Aldon, and C. LoSapio, editors. Desired future conditions for pinyon-juniper ecosystems, Flagstaff, AZ. USDA Forest Service Gen. Tech. Rep. RM-GTR-258, Fort Collins, CO.

Kruse, W. H., R. P. Balda, M. J. Simono, A. M. MacRander, and C. D. Johnson. 1979. Community-development in two adjacent pinyon-juniper eradication areas 25 years after treatment. Journal of Environmental Management 8:237-247.

Kundaeli, J. N., and H. G. Reynolds. 1972. Desert cottontail use of natural and modified pinyonjuniper woodland. Journal of Range Management 25:116.

McIver, J., and E. Macke. 2014. Short-term butterfly response to sagebrush steppe restoration treatments. Rangeland Ecology and Management 67:539-552.

Miller, R. F. 2001. Managing western juniper for wildlife. Woodland Fish and Wildlife. World Forestry Center. Portland, Oregon. Pages 89-97.

Miller, R. F., and J. A. Rose. 1995. Historic expansion of Juniperus occidentalis (Western juniper) in southeastern Oregon. The Great Basin Naturalist 55:37-45.

Miller, R. F., and J. A. Rose. 1999. Fire history and western juniper encroachment in sagebrush steppe. Journal of Range Management 52:550.

Miller, R. F., T. Svejcar, and J. A. Rose. 2000. Impacts of western juniper on plant community composition and structure. Journal of Range Management, 53:574-585.

Miller, R. F., and P. E. Wigand. 1994. Holocene changes in semiarid pinyon-juniper woodlands. BioScience 44:465-474. 
MontBlanc, E. M., J. C. Chambers, and P. F. Brussard. 2007. Variation in ant populations with elevation, tree cover, and fire in a pinyon-juniper-dominated watershed. Western North American Naturalist 67:469-491.

Mueller, R. C., C. M. Scudder, M. E. Porter, R. Talbot Trotter, C. A. Gehring, and T. G. Whitham. 2005. Differential tree mortality in response to severe drought: evidence for longterm vegetation shifts: Drought-induced differential tree mortality. Journal of Ecology 93:1085-1093.

Natural Resources Conservation Service. 2015. Sage grouse initiative 2.0 investment strategy, FY 2015-2018. 20 pages. USDA.

Noson, A. C., R. A. Schmitz, and R. F. Miller. 2006. Influence of fire and juniper encroachment on birds in high-elevation sagebrush steppe. Western North American Naturalist 66:343353.

O’Meara, T. E., J. B. Haufler, L. H. Stelter, and J. G. Nagy. 1981. Wildlife responses to chaining of pinyon-juniper woodlands. The Journal of Wildlife Management 45:381-389.

Paulin, K. M., J. J. Cook, and S. R. Dewey. 1999. Juniper woodlands as sources of avian diversity. Pages 240-243 in S. B. Monsen and Stevens, editors. Proceedings: ecology and management of pinyon-juniper communities within the Interior West. USDA Forest Service Proceedings RMRS-P-9, Ogden, UT.

Paulson, D. D., and C. H. Sieg. 1984. Long-eared owls nesting in Badlands National Park. South Dakota Bird Notes 36:72-75.

Pavlacky, D. C., and S. H. Anderson. 2001. Habitat preferences of pinyon-juniper specialists near the limit of their geographic range. The Condor 103:322. 
Pieper, R. D. 1990. Overstory-understory relations in pinyon-juniper woodlands in New Mexico. Journal of Range Management 43:413-415.

Plummer, A. P., D. R. Christensen, and S. B. Monsen. 1968. Restoring big game range in Utah. Page 183. Utah Division of Fish and Game Publication 68-3, Salt Lake City, UT.

Poulsen, C. L., S. C. Walker, and R. Stevens. 1999. Soil seed banking in pinyon-juniper areas with differing levels of tree cover, understory density and composition. Pages 141-145 in S. B. Monsen and R. Stevens, editors. Proceedings: ecology and management of pinyonjuniper communities within the Interior West. USDA Forest Service Proceedings RMRS-P9, Ogden, UT.

Pullin, A. S., and G. B. Stewart. 2006. Guidelines for systematic review in conservation and environmental management. Conservation Biology 20:1647-1656.

Pyke, D. A. 2011. Restoring and Rehabilitating Sagebrush Habitats. Pages 531-548 in S. T. Knick, J. W. Connelly, and Cooper Ornithological Society, editors. Greater sage-grouse: ecology and conservation of a landscape species and its habitats. University of California Press, Berkeley, California, USA.

Radke, N., D. Wester, G. Perry, and S. Rideout-Hanzak. 2008. Short-term effects of prescribed fire on lizards in mesquite-ashe juniper vegetation in central Texas. Applied Herpetology $5: 281-292$

Ranglack, D. H., and J. T. du Toit. 2015. Wild bison as ecological indicators of the effectiveness of management practices to increase forage quality on open rangeland. Ecological Indicators 56:145-151. 
Redmond, M. D., N. S. Cobb, M. E. Miller, and N. N. Barger. 2013. Long-term effects of chaining treatments on vegetation structure in pinon-juniper woodlands of the Colorado Plateau. Forest Ecology and Management 305:120-128.

Redmond, M. D., E. S. Golden, N. S. Cobb, and N. N. Barger. 2014. Vegetation management across Colorado Plateau BLM lands: 1950-2003. Rangeland Ecology \& Management 67:636-640.

Reemts, C. M., and D. A. Cimprich. 2014. Restoring early-successional shrubland habitat for black-capped vireos using mechanical mastication. Natural Areas Journal 34:400-407.

Ribble, D. O., and F. B. Samson. 1987. Microhabitat associations of small mammals in southeastern Colorado, with special emphasis on Peromyscus (Rodentia). Southwestern Naturalist 32:291-303.

Rodhouse, T. J., R. P. Hirnyck, and R. G. Wright. 2010. Habitat selection of rodents along a piñon-juniper woodland-savannah gradient. Journal of Mammalogy 91:447-457.

Romme, W. H., C. D. Allen, J. D. Bailey, W. L. Baker, B. T. Bestelmeyer, P. M. Brown, K. S. Eisenhart, M. L. Floyd, D. W. Huffman, B. F. Jacobs, R. F. Miller, E. H. Muldavin, T. W. Swetnam, R. J. Tausch, and P. J. Weisberg. 2009. Historical and modern disturbance regimes, stand structures, and landscape dynamics in piñon-juniper vegetation of the western United States. Rangeland Ecology and Management 62:203-222.

Rompola, K., and S. Anderson. 2004. Habitat of three rare species of small mammals in juniper woodlands of southwestern Wyoming. Western North American Naturalist 64:86-92.

Roundy, B. A., and J. L. Vernon. 1999. Watershed values and conditions associated with pinyonjuniper communities. Pages 172-187 in S. B. Monsen and R. Stevens, editors. Proceedings: 
ecology and management of pinyon-juniper communities within the Interior West. USDA Forest Service Proceedings RMRS-P-9, Ogden, UT.

Rowland, M. M., M. J. Wisdom, L. H. Suring, and C. W. Meinke. 2006. Greater sage-grouse as an umbrella species for sagebrush-associated vertebrates. Biological Conservation 129:323335.

Sabol, T. D. 2005. Effects of western juniper (Juniperus occidentalis) removal on avian species composition in shrub-steppe habitat in southcentral Oregon. Master's thesis. Southern Oregon University, Ashland, Oregon. 50 pages.

Sandford, C., and T. A. Messmer. 2015. Effects of pinyon juniper removal on greater sagegrouse (centrocercus urophasianus) habitat-use and vital rates in northwestern Utah. Pages 1-14. 2014 Annual Report (DWR Contract 132573), Utah State University, Logan, Utah.

Schoennagel, T., and C. R. Nelson. 2011. Restoration relevance of recent National Fire Plan treatments in forests of the western United States. Frontiers in Ecology and the Environment $9: 271-277$.

Scott, V. E., and E. L. Boeker. 1977. Responses of Merriam’s Turkey to pinyon-juniper control. Journal of Range Management 30:220-223.

Sedgwick, J. A., and R. A. Ryder. 1987. Effects of chaining pinyon-juniper on nongame wildlife. Proceedings: pinyon-juniper conference. USDA Forest Service Gen. Tech. Rep. INT-GTR215, Ogden, UT.

Severson, K. E. 1986. Small mammals in modified pinyon-juniper woodlands, New Mexico. Journal of Range Management 39:31-34.

Short, H. L., W. Evans, and E. L. Boeker. 1977. The use of natural and modified pinyon pinejuniper woodlands by deer and elk. Journal of Wildlife Management 41:543-559. 
Short, H. L., and C. Y. McCulloch. 1977. Managing pinyon-juniper ranges for wildlife. USDA Forest Service Gen. Tech. Rep. RM-47, Fort Collins, CO.

Sieg, C. H. 1988. The value of Rocky Mountain juniper (Juniperus scopulorum) woodlands in South Dakota as small mammal habitat. Pages 328-332 in R. C. Szaro, K. E. Severson, and D. R. Patton, editors. Management of amphibians, reptiles, and small mammals in North America: Proceedings of the symposium; 1988 July 19-21. Fort Collins, CO: U.S. Department of Agriculture, Rocky Mountain Forest and Range Experiment Station.

Sieg, C. H. 1991. Rocky-mountain juniper woodlands - year-round avian habitat. Pages 1-7. Research Paper, USDA Forest Service, Rocky Mountain Forest and Range Experiment Station, Fort Collins, CO.

Smith, C. B., and P. J. Urness. 1984. Small mammal abundance on native and improved Foothill Ranges, Utah. Journal of Range Management 37:353-357.

Smith, T., S., P. Hardin J., and J. T. Flinders. 1999. Response of bighorn sheep to clear-cut logging and prescribed burning. Wildlife Society Bulletin 27:840-845.

Stevens, R. 1987. Thirty years of pinyon-juniper big game habitat improvement projects: what have we learned. Pages 558-571 in R. L. Everett, editor. Proceedings: pinyon-juniper conference, Reno, NV. USDA Forest Service Gen. Tech. Rep. INT-215, Ogden, UT.

Stevens, R. 1999. Restoration of native communities by chaining and seeding. Pages $285-289$ in Proceedings: Ecology and management of pinyon-juniper communities within the Interior West, Proceedings RMRS-P-9. USDA Forest Service, Rocky Mountain Research Station, Ogden, Utah, USA.

Stevens, R. and S. C. Walker. 1996. Juniper-pinyon population dynamics over 30 years following anchor chaining. in: Barrow, Jerry, R; McArthur, E. Durrant; Sosebee, Ronald, 
E.; Tausch, Robin, J., editors. Proceedings: Shrubland ecosystem dynamics in a changing environment, Las Cruces, NM. USDA Forest Service Gen. Tech. Rep. INT-338. Ogden, UT $125-128$.

Sutherland, W. J., A. S. Pullin, P. M. Dolman, and T. M. Knight. 2004. The need for evidencebased conservation. Trends in Ecology \& Evolution 19:305-308.

Tausch, R. J., and P. T. Tueller. 1977. Plant succession following chaining of pinyon-juniper woodlands in eastern Nevada. Journal of Range Management 30:44-49.

Tausch, R. J., and P. T. Tueller. 1995. Relationships among plant species composition and mule deer winter range use on eastern Nevada pinyon-juniper chainings. Pages 65-73 in D. W. Shaw, E. F. Aldon, and C. LoSapio, editors. Desired future conditions for pinyon-juniper ecosystems, Flagstaff, AZ. USDA Forest Service Gen. Tech. Rep. RM-GTR-258.

Tausch, R. J., and N. E. West. 1995. Plant species composition patterns with differences in tree dominance on a southwestern Utah pinyon-juniper site. in D. W. Shaw, E. F. Aldon, and C. LoSapio, editors. Desired future conditions for pinyon-juniper ecosystems, Flagstaff, AZ. USDA Forest Service Gen. Tech. Rep. RM-GTR-258.

Tausch, R. J., N. E. West, and A. A. Nabi. 1981. Tree age and dominance patterns in great-basin pinyon-juniper woodlands. Journal of Range Management 34:259-264.

Turkowski, F. H., and H. G. Reynolds. 1970. Response of some rodent populations to pinyonjuniper reductions on the Kaibab Plateau, Arizona. Southwest Naturalist 15:23-27.

Turkowski, F. J., and R. K. Watkins. 1976. White-throated woodrat (Neotoma albigula) habitat relations in modified pinyon-juniper woodland of southwestern New Mexico. Journal of Mammalogy 57:586-591. 
U.S. Bureau of Land Management. 2011. Notice of intent to prepare environmental impact statements and supplemental environmental impact statements to incorporate greater sagegrouse conservation measures into land use plans and land management plans. Pages 76:77008-77011. Notice of Intent, Federal Register.

Van Horne, B. 1983. Density as a misleading indicator of habitat quality. The Journal of Wildlife Management 47:893-901.

Van Pelt, N. S., R. Stevens, and N. E. West. 1990. Survival and growth of immature Juniperus osteosperma and Pinus edulis following woodland chaining in central Utah. The Southwestern Naturalist 35:322-328.

Webb, M. 1999. Importance of pinyon-juniper Habitat to Birds. Pages 244-248 in S. B. Monsen and R. Stevens, editors. Proceedings: ecology and management of pinyon-juniper communities within the Interior West. USDA Forest Service Proceedings RMRS-P-9, Ogden, UT.

West, N. E. 1984. Successional patterns and productivity potentials of pinyon-juniper ecosystems. Pages 1301-1332 in United States National Research Council, editor. Developing strategies for rangeland management. Westview Press, Boulder, CO.

West, N. E. 1988. Intermountain deserts, shrub steppes, and woodlands. Pages 209-230 in M. G. Barbour and W. D. Billings, editors. North American terrestrial vegetation. Cambridge University Press, Cambridge, England.

Willis, M. J., and R. F. Miller. 1999. Importance of western juniper communities to small mammals. Pages 210-214 in S. B. Monsen and R. Stevens, editors. Proceedings: ecology and management of pinyon-juniper communities within the Interior West. USDA Forest Service Proceedings RMRS-P-9, Ogden, UT. 


\subsection{APPENDICES}

Appendix A. Keywords used in Web of Science and Google Scholar literature searches to locate studies on the effects of woodland reduction on wildlife.

\section{pin* OR juniper}

\section{AND any of the following:}

wildlife, animal, reptile, lizard, amphibian, frog, toad, snake, salamander, bird, raptor, mammal, rodent, rabbit, bat, predator, carnivore, mustelid, herbivore, game species, ungulate, insect, invertebrate, arthropod, omnivore, fish

\section{AND any of the following:}

treatment, tree removal, woodland reduction, woodland clearing, habitat manipulation, chain*, cut*, mow*, prescribed fire, prescribed burn*, cabl*, bulldoz*, mulch*, masticat* thin* 
Appendix B. Summary of studies that have evaluated wildlife responses to pinyon and juniper woodland reduction treatments.

\begin{tabular}{|c|c|c|c|c|c|c|c|}
\hline Study & $\begin{array}{l}\text { Treatment } \\
\text { type(s) }\end{array}$ & $\begin{array}{l}\text { Sampling } \\
\text { period }\end{array}$ & Location(s) & $\begin{array}{l}\text { Size of } \\
\text { treatment } \\
\text { (ha) }\end{array}$ & $\begin{array}{l}\text { Wildlife } \\
\text { studied }\end{array}$ & $\begin{array}{l}\text { Effect } \\
\text { Measured }\end{array}$ & $\begin{array}{l}\text { Included in } \\
\text { analysis or } \\
\text { reason } \\
\text { excluded }\end{array}$ \\
\hline $\begin{array}{l}\text { Turkowski } \\
\text { and Reynolds } \\
1970\end{array}$ & Bulldozing & $\begin{array}{l}7-8 \text { years } \\
\text { post } \\
\text { treatment }\end{array}$ & $\begin{array}{l}\text { Kaibab } \\
\text { Plateau, } \\
\text { Arizona }\end{array}$ & Unknown & $\begin{array}{l}\text { Small } \\
\text { mammals }\end{array}$ & $\begin{array}{l}\text { Counts } \\
\text { (no./300 trap } \\
\text { nights) }\end{array}$ & $\begin{array}{l}\text { Did not test for } \\
\text { significant } \\
\text { differences } \\
\text { between } \\
\text { treatments and } \\
\text { controls }\end{array}$ \\
\hline $\begin{array}{l}\text { Kundaeli and } \\
\text { Reynolds } \\
1972\end{array}$ & $\begin{array}{l}\text { Uprooting } \\
\text { all, thinning, } \\
\text { Uprooting \& } \\
\text { burning }\end{array}$ & $\begin{array}{l}2 \text { years } \\
\text { pre and } 3 \\
\text { years post } \\
\text { treatment }\end{array}$ & $\begin{array}{l}\text { Ft. Bayard } \\
\text { Experimental } \\
\text { Forest, New } \\
\text { Mexico }\end{array}$ & $120-200$ & $\begin{array}{l}\text { Desert } \\
\text { cottontail }\end{array}$ & $\begin{array}{l}\text { Pellet counts } \\
\left(\text { no. } / \mathrm{ft}^{2}\right)\end{array}$ & Included \\
\hline $\begin{array}{l}\text { Baker and } \\
\text { Frischknecht } \\
1973\end{array}$ & $\begin{array}{l}\text { Chained \& } \\
\text { seeded, } \\
\text { Chained \& } \\
\text { windrowed }\end{array}$ & $\begin{array}{l}1 \text { year pre } \\
\text { and } 2-3 \\
\text { years post } \\
\text { treatment }\end{array}$ & $\begin{array}{l}\text { Tintic and } \\
\text { Sheeprock } \\
\text { Mountain, } \\
\text { Utah }\end{array}$ & $\sim 120$ & $\begin{array}{l}\text { Small } \\
\text { mammals }\end{array}$ & $\begin{array}{l}\text { Counts (total } \\
\text { \# captured) }\end{array}$ & $\begin{array}{l}\text { Did not test for } \\
\text { significant } \\
\text { differences } \\
\text { between } \\
\text { treatments and } \\
\text { controls }\end{array}$ \\
\hline $\begin{array}{l}\text { Howard and } \\
\text { Wolfe } 1976\end{array}$ & $\begin{array}{l}\text { Multiple } \\
\text { range } \\
\text { improvemen } \\
\text { t practices }\end{array}$ & NA & $\begin{array}{l}\text { Black Pine } \\
\text { Mountains, } \\
\text { Utah }\end{array}$ & NA & $\begin{array}{l}\text { Ferrugino } \\
\text { us Hawks }\end{array}$ & NA & $\begin{array}{l}\text { Does not } \\
\text { empirically test } \\
\text { woodland } \\
\text { reduction } \\
\text { effects; only } \\
\text { discusses } \\
\text { potential effects } \\
\text { based on habitat } \\
\text { requirements }\end{array}$ \\
\hline $\begin{array}{l}\text { Turkowski } \\
\text { and Watkins } \\
1976\end{array}$ & $\begin{array}{l}\text { Partial } \\
\text { bulldozing; } \\
\text { Complete } \\
\text { bulldozing; } \\
\text { Bulldozing } \\
\text { and burning; } \\
\text { Thinning }\end{array}$ & $\begin{array}{l}1 \text { year pre } \\
\text { and } 2 \text { and } \\
7 \text { years } \\
\text { post- } \\
\text { treatment }\end{array}$ & $\begin{array}{l}\text { Bayard } \\
\text { watershed, } \\
\text { New Mexico }\end{array}$ & 120 & $\begin{array}{l}\text { White- } \\
\text { throated } \\
\text { woodrat }\end{array}$ & $\begin{array}{l}\text { Average no. } \\
\text { of woodrat } \\
\text { houses per } \\
\text { hectare }\end{array}$ & $\begin{array}{l}\text { Did not test for } \\
\text { significant } \\
\text { differences } \\
\text { between } \\
\text { treatments and } \\
\text { controls }\end{array}$ \\
\hline $\begin{array}{l}\text { Scott and } \\
\text { Boeker } 1977\end{array}$ & $\begin{array}{l}\text { Chaining \& } \\
\text { burning }\end{array}$ & $\begin{array}{l}4 \text { years } \\
\text { pre and } 4 \\
\text { years post } \\
\text { treatment }\end{array}$ & $\begin{array}{l}\text { Fort Apache } \\
\text { Indian } \\
\text { Reservation, } \\
\text { Arizona }\end{array}$ & 300 & $\begin{array}{l}\text { Merriam's } \\
\text { Turkey }\end{array}$ & $\begin{array}{l}\text { Mean no. } \\
\text { turkeys/km }\end{array}$ & $\begin{array}{l}\text { Did not test for } \\
\text { significant } \\
\text { differences } \\
\text { between } \\
\text { treatments and } \\
\text { controls }\end{array}$ \\
\hline $\begin{array}{l}\text { Short et al. } \\
1977\end{array}$ & $\begin{array}{l}\text { Thinning, } \\
\text { partial } \\
\text { removal } \\
\text { (bulldozing), } \\
\text { complete }\end{array}$ & $\begin{array}{l}4 \text { years } \\
\text { pre and } \\
\text { post } \\
\text { treatment }\end{array}$ & $\begin{array}{l}\text { Fort Bayard, } \\
\text { New Mexico }\end{array}$ & $\begin{array}{l}\sim 100 \\
(1 \mathrm{~km} \mathrm{x} \\
1 \mathrm{~km} \text { plots })\end{array}$ & $\begin{array}{l}\text { Mule deer } \\
\text { and Elk }\end{array}$ & $\begin{array}{l}\text { Pellet counts } \\
(\text { no./km2) }\end{array}$ & Included \\
\hline
\end{tabular}




\begin{tabular}{|c|c|c|c|c|c|c|c|}
\hline & $\begin{array}{l}\text { removal, } \\
\text { complete } \\
\text { removal }+ \\
\text { burned slash } \\
\end{array}$ & & & & & & \\
\hline $\begin{array}{l}\text { Kruse et al. } \\
1979\end{array}$ & Bulldozing & $\begin{array}{l}26 \text { years } \\
\text { post- } \\
\text { treatment }\end{array}$ & $\begin{array}{l}\text { Drake, } \\
\text { Arizona }\end{array}$ & $\begin{array}{l}40 ? \text { Not } \\
\text { indicated } \\
\text { in paper, } \\
\text { but birds } \\
\text { are } \\
\text { estimated } \\
\text { per } 40 \text { ha }\end{array}$ & $\begin{array}{l}\text { Small } \\
\text { mammals, } \\
\text { rabbits, } \\
\text { deer, } \\
\text { pronghorn } \\
\text {, and birds }\end{array}$ & $\begin{array}{l}\text { Small } \\
\text { mammal } \\
\text { counts (total } \\
\text { \# captured); } \\
\text { rabbit and } \\
\text { ungulate } \\
\text { pellet } \\
\text { counts; bird } \\
\text { transects } \\
\text { (no. } \\
\text { birds/100 } \\
\text { ha) }\end{array}$ & $\begin{array}{l}\text { Did not test for } \\
\text { significant } \\
\text { differences } \\
\text { between } \\
\text { treatments and } \\
\text { controls }\end{array}$ \\
\hline $\begin{array}{l}\text { O'Meara et al. } \\
1981\end{array}$ & Chaining & $\begin{array}{l}1,8,10, \\
\text { and } 15 \\
\text { years post } \\
\text { treatment }\end{array}$ & $\begin{array}{l}\text { Piceance } \\
\text { Basin, } \\
\text { Colorado }\end{array}$ & $12-16$ & $\begin{array}{l}\text { Small } \\
\text { mammals } \\
\text { and birds }\end{array}$ & $\begin{array}{l}\text { Small } \\
\text { mammal } \\
\text { counts (total } \\
\text { \# captured); } \\
\text { Bird } \\
\text { densities } \\
\text { (no. } \\
\text { territories/10 } \\
\text { ha) }\end{array}$ & $\begin{array}{l}\text { Used for deer } \\
\text { mice and least } \\
\text { chipmunks } \\
\text { only. Did not } \\
\text { test for } \\
\text { significant } \\
\text { differences } \\
\text { between } \\
\text { treatments and } \\
\text { controls for } \\
\text { other species. }\end{array}$ \\
\hline $\begin{array}{l}\text { Smith and } \\
\text { Urness } 1984\end{array}$ & Burning & $\begin{array}{l}30-32 \\
\text { years } \\
\text { post- } \\
\text { treatment }\end{array}$ & $\begin{array}{l}\text { Tintic Valley, } \\
\text { Utah }\end{array}$ & 28 & $\begin{array}{l}\text { Small } \\
\text { mammals }\end{array}$ & $\begin{array}{l}\text { Counts (total } \\
\text { \# captured } \\
\text { from 1978- } \\
1980 \text { ) }\end{array}$ & Included \\
\hline $\begin{array}{l}\text { Severson } \\
1986\end{array}$ & $\begin{array}{l}\text { Bulldozing, } \\
\text { burning, } \\
\text { thinning }\end{array}$ & $\begin{array}{l}11-19 \\
\text { years post } \\
\text { treatment }\end{array}$ & $\begin{array}{l}\text { Fort Bayard, } \\
\text { New Mexico }\end{array}$ & $\sim 120$ & $\begin{array}{l}\text { Small } \\
\text { mammals }\end{array}$ & $\begin{array}{l}\text { Small } \\
\text { mammal } \\
\text { counts (total } \\
\text { \# captured) }\end{array}$ & Included \\
\hline $\begin{array}{l}\text { Howard et al. } \\
1987\end{array}$ & $\begin{array}{l}\text { 2-way } \\
\text { cabling }\end{array}$ & $\begin{array}{l}1-7 \text { years, } \\
\text { and } 21-27 \\
\text { years post } \\
\text { treatment }\end{array}$ & $\begin{array}{l}\text { Fort Stanton } \\
\text { and Lincoln } \\
\text { National } \\
\text { Forest, New } \\
\text { Mexico }\end{array}$ & $2.6-11.0$ & $\begin{array}{l}\text { Mule deer } \\
\text { and } \\
\text { lagomorp } \\
\text { hs }\end{array}$ & $\begin{array}{l}\text { Pellet } \\
\text { deposition } \\
\text { rates (mule } \\
\text { deer = } \\
\text { groups/ha/ } \\
\text { day); } \\
\text { lagomorphs } \\
=\text { pellets/ha/ } \\
\text { day }\end{array}$ & Included \\
\hline $\begin{array}{l}\text { Sedgwick and } \\
\text { Ryder } 1987\end{array}$ & Chaining & $\begin{array}{l}1 \text { year pre } \\
\text { and } 4 \\
\text { years post } \\
\text { treatment }\end{array}$ & $\begin{array}{l}\text { Piceance } \\
\text { Basin, } \\
\text { Colorado }\end{array}$ & $\begin{array}{l}6.8 \text { and } \\
5.2\end{array}$ & $\begin{array}{l}\text { Small } \\
\text { mammals } \\
\text { and birds }\end{array}$ & $\begin{array}{l}\text { Bird counts } \\
\text { (no./100ha); } \\
\text { small } \\
\text { mammal } \\
\text { counts (total } \\
\text { \# captured) }\end{array}$ & Included \\
\hline $\begin{array}{l}\text { Barnitz et al. } \\
1990\end{array}$ & $\begin{array}{l}\text { 2-way } \\
\text { cabling }\end{array}$ & $\begin{array}{l}1-7 \text { years, } \\
\text { and } 21-27 \\
\text { years post } \\
\text { treatment }\end{array}$ & $\begin{array}{l}\text { Fort Stanton } \\
\text { and Lincoln } \\
\text { National } \\
\text { Forest, New } \\
\text { Mexico }\end{array}$ & $2.6-11.0$ & $\begin{array}{l}\text { Mule deer } \\
\text { and } \\
\text { lagomorp } \\
\text { hs }\end{array}$ & $\begin{array}{l}\text { Pellet } \\
\text { deposition } \\
\text { rates (mule } \\
\text { deer }= \\
\text { groups/ha/ }\end{array}$ & $\begin{array}{l}\text { Duplicate of } \\
\text { data presented } \\
\text { in Howard et al. } \\
1987 \text { (published } \\
\text { paper) }\end{array}$ \\
\hline
\end{tabular}




\begin{tabular}{|c|c|c|c|c|c|c|c|}
\hline & & & & & & $\begin{array}{l}\text { day); } \\
\text { lagomorphs } \\
=\text { pellets/ha/ } \\
\text { day }\end{array}$ & \\
\hline $\begin{array}{l}\text { Albert et al. } \\
1994\end{array}$ & $\begin{array}{l}\text { Mechanical } \\
\text { thinning }\end{array}$ & $\begin{array}{l}0-2 \text { years } \\
\text { post } \\
\text { treatment }\end{array}$ & $\begin{array}{l}\text { Zuni } \\
\text { Reservation, } \\
\text { Arizona and } \\
\text { New Mexico }\end{array}$ & 1 & $\begin{array}{l}\text { Small } \\
\text { mammals, } \\
\text { birds, } \\
\text { mule deer }\end{array}$ & $\begin{array}{l}\text { Sm. } \\
\text { Mammal } \\
\text { counts } \\
\text { (no./ha/100 } \\
\text { trap nights); } \\
\text { Bird counts } \\
\text { (no./ha/2 } \\
\text { yrs.); mule } \\
\text { deer pellet } \\
\text { counts } \\
\text { (groups/ha) }\end{array}$ & $\begin{array}{l}\text { Did not test for } \\
\text { significant } \\
\text { differences } \\
\text { between } \\
\text { treatments and } \\
\text { controls }\end{array}$ \\
\hline $\begin{array}{l}\text { Tausch and } \\
\text { Tueller } 1995\end{array}$ & Chaining & $\begin{array}{l}2 \text { to } 13 \\
\text { years } \\
\text { post- } \\
\text { treatment }\end{array}$ & $\begin{array}{l}\text { Five sites in } \\
\text { eastern } \\
\text { Nevada }\end{array}$ & $\begin{array}{l}160- \\
1100\end{array}$ & Mule deer & $\begin{array}{l}\text { Deer days } \\
\text { use/acre }\end{array}$ & $\begin{array}{l}\text { No control } \\
\text { plots; only use } \\
\text { in different } \\
\text { treatment areas }\end{array}$ \\
\hline $\begin{array}{l}\text { Greenwood et } \\
\text { al. } 1997\end{array}$ & Burning & $\begin{array}{l}10 \text { to } 70 \\
\text { years } \\
\text { post- } \\
\text { treatment }\end{array}$ & $\begin{array}{l}\text { Daggett } \\
\text { County, Utah }\end{array}$ & Unknown & $\begin{array}{l}\text { Mountain } \\
\text { bighorn } \\
\text { sheep }\end{array}$ & Group size & $\begin{array}{l}\text { Observational } \\
\text { study; burned } \\
\text { areas not true } \\
\text { treatments }\end{array}$ \\
\hline $\begin{array}{l}\text { Commons et } \\
\text { al. } 1999\end{array}$ & $\begin{array}{l}\text { Mechanical } \\
\text { and hand- } \\
\text { cutting }\end{array}$ & $\begin{array}{l}1 \text { year pre } \\
\text { and } 1-3 \\
\text { years post } \\
\text { treatment }\end{array}$ & $\begin{array}{l}\text { Fruitland } \\
\text { Mesa, } \\
\text { Colorado }\end{array}$ & Unknown & $\begin{array}{l}\text { Sage } \\
\text { grouse } \\
\text { Centrocer } \\
\text { cus spp. }\end{array}$ & $\begin{array}{l}\text { Peak counts } \\
\text { of male sage } \\
\text { grouse on } \\
\text { leks }\end{array}$ & $\begin{array}{l}\text { Did not test for } \\
\text { significant } \\
\text { differences } \\
\text { between } \\
\text { treatments and } \\
\text { controls }\end{array}$ \\
\hline Kruse 1994 & $\begin{array}{l}\text { Fuelwood } \\
\text { harvesting }\end{array}$ & $\begin{array}{l}2 \text { year pre } \\
\text { and } 1-4 \\
\text { years post } \\
\text { treatment }\end{array}$ & $\begin{array}{l}\text { Herber } \\
\text { Ranger } \\
\text { District, } \\
\text { Arizona }\end{array}$ & 4 & $\begin{array}{l}\text { Small } \\
\text { mammals }\end{array}$ & $\begin{array}{l}\text { Counts (total } \\
\text { no. } \\
\text { captured/yr.) }\end{array}$ & Included \\
\hline $\begin{array}{l}\text { Smith et al. } \\
1999\end{array}$ & Burning & $\begin{array}{l}3 \text { years } \\
\text { pre and } 2 \\
\text { years post } \\
\text { treatment }\end{array}$ & $\begin{array}{l}\text { Flaming } \\
\text { Gorge } \\
\text { National } \\
\text { Recreation } \\
\text { Area, Utah }\end{array}$ & 65 & $\begin{array}{l}\text { Bighorn } \\
\text { sheep }\end{array}$ & $\begin{array}{l}\text { Group } \\
\text { counts (no. } \\
\text { groups } \\
\text { observed) }\end{array}$ & $\begin{array}{l}\text { Did not test for } \\
\text { significant } \\
\text { differences } \\
\text { between } \\
\text { treatments and } \\
\text { controls }\end{array}$ \\
\hline $\begin{array}{l}\text { Willis and } \\
\text { Miller } 1999\end{array}$ & $\begin{array}{l}\text { Cutting } \\
\text { (method not } \\
\text { stated) }\end{array}$ & $\begin{array}{l}1 \text { and } 3-5 \\
\text { years post } \\
\text { treatment }\end{array}$ & $\begin{array}{l}\text { Southeast } \\
\text { Oregon }\end{array}$ & $\sim 10$ & $\begin{array}{l}\text { Small } \\
\text { mammals }\end{array}$ & $\begin{array}{l}\text { Counts (total } \\
\text { no. } \\
\text { captured/yr.) }\end{array}$ & Included \\
\hline $\begin{array}{l}\text { Kleintjes et } \\
\text { al. } 2004\end{array}$ & $\begin{array}{l}\text { Cutting \& } \\
\text { slash } \\
\text { mulching }\end{array}$ & $\begin{array}{l}2 \& 4 \\
\text { years post } \\
\text { treatment }\end{array}$ & $\begin{array}{l}\text { Bandelier } \\
\text { National } \\
\text { Monument, } \\
\text { New Mexico }\end{array}$ & 40 & Butterflies & $\begin{array}{l}\text { Mean no. } \\
\text { butterflies } \\
\text { per transect; } \\
\text { Mean no. } \\
\text { species per } \\
\text { transect }\end{array}$ & Included \\
\hline Sabol 2005 & Cutting & $\begin{array}{l}1-2 \text { years } \\
\text { post- } \\
\text { treatment }\end{array}$ & $\begin{array}{l}\text { Gerber } \\
\text { Reservoir } \\
\text { watershed, } \\
\text { Oregon }\end{array}$ & $\begin{array}{l}580- \\
1780\end{array}$ & Birds & $\begin{array}{l}\text { Counts (total } \\
\text { number } \\
\text { observed) }\end{array}$ & Master's Thesis \\
\hline $\begin{array}{l}\text { Jehle et al. } \\
2006\end{array}$ & Burning & $\begin{array}{l}3 \text { to } 5 \\
\text { years }\end{array}$ & $\begin{array}{l}\text { Rocky } \\
\text { Mountain } \\
\text { National }\end{array}$ & $55-130$ & $\begin{array}{l}\text { Green- } \\
\text { tailed } \\
\text { towhee }\end{array}$ & No. birds/ha & Included \\
\hline
\end{tabular}




\begin{tabular}{|c|c|c|c|c|c|c|c|}
\hline & & $\begin{array}{l}\text { post- } \\
\text { treatment }\end{array}$ & $\begin{array}{l}\text { Park, } \\
\text { Colorado }\end{array}$ & & & & \\
\hline $\begin{array}{l}\text { Montblanc et } \\
\text { al. } 2007\end{array}$ & Burning & $\begin{array}{l}1 \text { year pre } \\
\text { and } 1 \text { year } \\
\text { post } \\
\text { treatment }\end{array}$ & $\begin{array}{l}\text { Shoshone } \\
\text { Mountain } \\
\text { Range, } \\
\text { Nevada } \\
\end{array}$ & .01 & Ants & $\begin{array}{l}\text { Mean } \\
\text { abundance }\end{array}$ & Included \\
\hline $\begin{array}{l}\text { Radke et al. } \\
2008\end{array}$ & Burning & $\begin{array}{l}1 \text { year } \\
\text { post- } \\
\text { treatment }\end{array}$ & $\begin{array}{l}\text { Blue } \\
\text { Mountain } \\
\text { Peak Ranch, } \\
\text { Texas }\end{array}$ & 0.2 & $\begin{array}{l}\text { Lizards } \\
\text { and } \\
\text { Inverte- } \\
\text { brates }\end{array}$ & $\begin{array}{l}\text { Mean } \\
\text { abundance } \\
\text { over all } \\
\text { sampling } \\
\text { periods }\end{array}$ & Included \\
\hline $\begin{array}{l}\text { Crow and van } \\
\text { Riper } 2010\end{array}$ & $\begin{array}{l}\text { Mechanical } \\
\text { thinning }\end{array}$ & $\begin{array}{l}1 \text { year pre } \\
\text { and } 1 \text { year } \\
\text { post } \\
\text { treatment }\end{array}$ & $\begin{array}{l}\text { Grand } \\
\text { Staircase } \\
\text { Escalante } \\
\text { National } \\
\text { Monument, } \\
\text { Utah }\end{array}$ & $\begin{array}{l}64.6 \text { and } \\
80.75\end{array}$ & Birds & $\begin{array}{l}\text { Mean } \\
\text { relative } \\
\text { abundance }\end{array}$ & Included \\
\hline $\begin{array}{l}\text { Bender et al. } \\
2013\end{array}$ & Thinning & Unknown & $\begin{array}{l}\text { Corona } \\
\text { Range and } \\
\text { Livestock } \\
\text { Research } \\
\text { Center, New } \\
\text { Mexico }\end{array}$ & 11,290 & Mule deer & $\begin{array}{l}\text { Body } \\
\text { condition }\end{array}$ & $\begin{array}{l}\text { Non-abundance } \\
\text { response } \\
\text { variable }\end{array}$ \\
\hline $\begin{array}{l}\text { Frey et al. } \\
2013\end{array}$ & $\begin{array}{l}\text { Cutting \& } \\
\text { slash } \\
\text { mulching }\end{array}$ & $\begin{array}{l}1 \text { year } \\
\text { pre- and } \\
1-4 \text { years } \\
\text { post- } \\
\text { treatment }\end{array}$ & $\begin{array}{l}\text { Sink Valley, } \\
\text { Utah }\end{array}$ & $\begin{array}{l}1720 \\
(8.6 \mathrm{~km} \mathrm{x} \\
2 \mathrm{~km})\end{array}$ & $\begin{array}{l}\text { Greater } \\
\text { sage } \\
\text { grouse }\end{array}$ & $\begin{array}{l}\% \text { use of } \\
\text { total } \\
\text { locations }\end{array}$ & Included \\
\hline $\begin{array}{l}\text { Knick et al. } \\
2014\end{array}$ & Burning & $\begin{array}{l}1 \text { year } \\
\text { pre- and } \\
1-5 \text { years } \\
\text { post- } \\
\text { treatment }\end{array}$ & 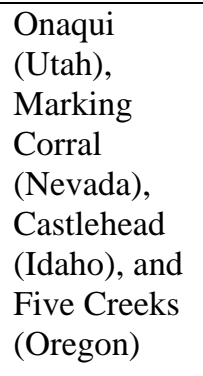 & $\begin{array}{l}393,418, \\
959 \text {, and } \\
1029\end{array}$ & $\begin{array}{l}\text { Sagebrush } \\
\text { obligate } \\
\text { birds }\end{array}$ & $\begin{array}{l}\text { Mean no. of } \\
\text { detections }\end{array}$ & Included \\
\hline $\begin{array}{l}\text { Bergman et } \\
\text { al. } 2014\end{array}$ & $\begin{array}{l}\text { Hydro-axe } \\
\text { or roller- } \\
\text { chop and } \\
\text { reseeding + } \\
\text { herbicide } \\
\end{array}$ & $\begin{array}{l}1-7 \text { years } \\
\text { post- } \\
\text { treatment }\end{array}$ & $\begin{array}{l}\text { San Juan } \\
\text { Mountains, } \\
\text { Colorado }\end{array}$ & $110-730$ & Mule deer & $\begin{array}{l}\text { Overwinter } \\
\text { survival rate }\end{array}$ & $\begin{array}{l}\text { Non-abundance } \\
\text { response } \\
\text { variable }\end{array}$ \\
\hline $\begin{array}{l}\text { McIver and } \\
\text { Macke } 2014\end{array}$ & $\begin{array}{l}\text { Prescribed } \\
\text { burning, } \\
\text { cutting, or } \\
\text { mowing }\end{array}$ & $\begin{array}{l}1 \text { year } \\
\text { pre- } \\
\text { treatment } \\
\text { and } 1-6 \\
\text { years } \\
\text { post- } \\
\text { treatment }\end{array}$ & $\begin{array}{l}\text { Oregon, } \\
\text { California, } \\
\text { Nevada, and } \\
\text { Utah }\end{array}$ & $10-20$ & Butterflies & $\begin{array}{l}\text { Mean total } \\
\text { abundance } \\
\text { over all } \\
\text { years and } \\
\text { replicates }\end{array}$ & Included \\
\hline $\begin{array}{l}\text { Reemts and } \\
\text { Cimprich } \\
2014\end{array}$ & $\begin{array}{l}\text { Hydro-axe } \\
\text { and felling }\end{array}$ & $\begin{array}{l}1 \text { year } \\
\text { pre- } \\
\text { treatment } \\
\text { and 1and } \\
4 \text { years }\end{array}$ & $\begin{array}{l}\text { Fort Hood, } \\
\text { Texas }\end{array}$ & $5-13$ & $\begin{array}{l}\text { Black- } \\
\text { capped } \\
\text { vireos }\end{array}$ & $\begin{array}{l}\text { No. of vireo } \\
\text { territories }\end{array}$ & Included \\
\hline
\end{tabular}




\begin{tabular}{|c|c|c|c|c|c|c|c|}
\hline & & $\begin{array}{l}\text { post- } \\
\text { treatment }\end{array}$ & & & & & \\
\hline $\begin{array}{l}\text { Higgins et al. } \\
2014\end{array}$ & Burning & $\begin{array}{l}\text { 5-6 years } \\
\text { post- } \\
\text { treatment }\end{array}$ & $\begin{array}{l}\text { Mesa Verde } \\
\text { National } \\
\text { Park, } \\
\text { Colorado }\end{array}$ & Unknown & $\begin{array}{l}\text { Invertebra } \\
\text { tes }\end{array}$ & $\begin{array}{l}\text { Arthropod } \\
\text { abundance }\end{array}$ & $\begin{array}{l}\text { Observational } \\
\text { study; burned } \\
\text { areas not true } \\
\text { treatments }\end{array}$ \\
\hline $\begin{array}{l}\text { Bergman et } \\
\text { al. } 2015\end{array}$ & $\begin{array}{l}\text { Hydro-axe } \\
\text { or roller- } \\
\text { chop and } \\
\text { reseeding + } \\
\text { herbicide }\end{array}$ & $\begin{array}{l}1-7 \text { years } \\
\text { post- } \\
\text { treatment }\end{array}$ & $\begin{array}{l}\text { San Juan } \\
\text { Mountains, } \\
\text { Colorado }\end{array}$ & $110-730$ & Mule deer & $\begin{array}{l}\text { Density } \\
\text { (deer/km2) }\end{array}$ & Included \\
\hline $\begin{array}{l}\text { Ranglack and } \\
\text { du Toit } 2015\end{array}$ & $\begin{array}{l}\text { Prescribed } \\
\text { burn or } \\
\text { chaining }\end{array}$ & $\begin{array}{l}8 \text { years } \\
\text { (burning); } \\
\sim 55 \text { years } \\
\text { (chaining) }\end{array}$ & $\begin{array}{l}\text { Henry } \\
\text { Mountains, } \\
\text { Utah }\end{array}$ & $\begin{array}{l}14,600 \\
\text { (burned); } \\
243 \\
\text { (chained) }\end{array}$ & Bison & $\begin{array}{l}\text { Herd size, } \\
\text { herd } \\
\text { composition, } \\
\text { fecal } \\
\text { parasite } \\
\text { load, body } \\
\text { condition, } \\
\text { Fecal N, } \\
\text { foraging } \\
\text { time }\end{array}$ & $\begin{array}{l}\text { Treatments } \\
\text { compared to } \\
\text { multiple habitat } \\
\text { types } \\
\text { simultaneously } \\
\text { (aspen } \\
\text { woodland, } \\
\text { coniferous } \\
\text { woodland, } \\
\text { oakbrush,conife } \\
\text { rous woodland) } \\
\text { not comparable } \\
\text { to other studies }\end{array}$ \\
\hline $\begin{array}{l}\text { Sandford and } \\
\text { Messmer } \\
2015\end{array}$ & $\begin{array}{l}\text { Mastication } \\
\text { and chaining }\end{array}$ & Unknown & $\begin{array}{l}\text { West Box } \\
\text { Elder } \\
\text { Resource } \\
\text { Area, Utah }\end{array}$ & Unknown & $\begin{array}{l}\text { Greater } \\
\text { sage } \\
\text { grouse }\end{array}$ & Vital rates & $\begin{array}{l}\text { Preliminary } \\
\text { results }\end{array}$ \\
\hline
\end{tabular}


Appendix C. Species included in our analysis were assigned to functional groups as indicated below. Functional group assignments were based on the types of habitats that each species used, according to information extracted from the Cornell Birds of North America Online database (birds) or the International Union for the Conservation of Nature (all non-bird species). We defined each functional group as follows: generalists are species that commonly use $>2$ habitat types; sagebrush obligates are species that rarely occur outside sagebrush habitat; shrublandgrassland species are those that use both of these habitats but are not obligates to either; woodland species are those that rarely occur outside of woodlands or woodland edges; and woodland-shrubland species are those that use both of these habitats but are not obligates to either.

\begin{tabular}{|c|c|}
\hline Common name & Scientific name \\
\hline \multicolumn{2}{|l|}{ Generalist } \\
\hline Bushy-tailed woodrat & Neotoma cinerea \\
\hline Deer mice & Peromyscus maniculatus \\
\hline Desert cottontail & Sylvilagus audubonii \\
\hline Elk & Cervus canadensis \\
\hline Golden-mantled ground squirrel & Callospermophilus lateralis \\
\hline Long-tailed voles & Microtus longicaudus \\
\hline Mountain bluebird & Sialia currucoides \\
\hline Mourning dove & Zenaida macroura \\
\hline Mule deer & Odocoileus hemionus \\
\hline Western (pacific) jumping mice & Zapus princeps \\
\hline \multicolumn{2}{|l|}{ Sagebrush obligate } \\
\hline Brewers sparrow & Spizella breweri \\
\hline Greater sage grouse & Centrocercus urophasianus \\
\hline Sage thrasher & Oreoscoptes montanus \\
\hline Sagebrush sparrow & Artemisiospiza nevadensis \\
\hline Sagebrush vole & Lemmiscus curtatus \\
\hline \multicolumn{2}{|l|}{ Shrubland-Grassland } \\
\hline Canyon mice & Peromyscus crinitus \\
\hline Great Basin pocket mice & Perognathus parvus \\
\hline Legume-feeding blues & Everes spp., Glaucopsyche spp., Plebejus spp. \\
\hline Legume-feeding sulphurs & Colias spp. \\
\hline Melissa blue & Plebejus melissa \\
\hline
\end{tabular}


Montane vole

Mustard-feeding "local", whites

Mustard-feeding "transient'" whites

Northern pocket gopher

Ord's kangaroo rat

Plains pocket mouse

Rock wren

Spotted towhee

Vesper sparrow

Violet-feeding fritillaries

Western harvest mice

Varies-multiple species pooled in study

Ants

Butterflies

Acari spp.

Araneae spp.

Coleoptera spp.

Collembola spp.

Dictyoptera spp.

Diplopoda spp.

Diptera spp.

Hemiptera spp.

Homoptera spp.

Hymenoptera spp.

Isopoda spp.

Lepidoptera spp.

Microcoryphia spp.

Opoliones spp.

Orthoptera spp.

Thysanoptera spp.

Chipmunks

Lizards

Rabbits

\section{Woodland}

Black-throated grey warbler

Dark-eyed junco

Hairy woodpecker

Hermit thrush

Mountain chickadee

Plain titmouse (Juniper titmouse)

Solitary vireo (Plumbeous vireo)
Microtus montanus

Euchloe, Anthocharis

Pieris spp., Pontia spp.

Thomomys talpoides

Dipodomys ordii

Perognathus flavescens

Salpinctes obsoletus

Pipilo maculatus

Pooecetes gramineus

Speyeria spp.

Reithrodontomys megalotis

Hymenoptera spp.

Lepidoptera spp.
Tamias spp.

Lacertilia spp.

Lagomorpha spp.

Setophaga nigrescens

Junco hyemalis

Leuconotopicus villosus

Catharus guttatus

Poecile gambeli

Baeolophus ridgwayi

Vireo plumbeus 
Vagrant shrew

White-breasted nuthatch

\section{Woodland-Shrubland}

Ash-throated flycatcher

Black-headed grosbeak

Blue-gray gnatchatcher

Brush mice

American bushtit

Chipping sparrow

Cliff chipmunk

Dusky flycatcher

Gray flycatcher

Gray vireo

House wren

Juniper hairstreak

Least chipmunk

Mountain cottontail

Pinon mouse

Scrub jay

Uinta chipmunk

White-throated woodrat

Yellow pine chipmunk
Sorex vagrans

Sitta carolinensis

Myiarchus cinerascens

Pheucticus melanocephalus

Polioptila caerulea

Peromyscus boylii

Psaltriparus minimus

Spizella passerine

Tamias dorsalis

Empidonax oberholseri

Empidonax wrightii

Vireo vicinior

Troglodytes aedon

Callophrys gryneus

Tamias minimus

Sylvilagus nuttallii

Peromyscus truei

Aphelocoma californica

Tamias umbrinus

Neotoma albigula

Tamias amoenus 